\title{
Managerial Risk Tolerance and Corporate Credit Ratings*
}

\author{
Zhiyan Cao \\ Milgard School of Business, University of Washington Tacoma \\ Jeong Bon Kim \\ City University of Hong Kong \\ Eliza Xia Zhang \\ Milgard School of Business, University of Washington Tacoma \\ Ray Zhang \\ Beedie School of Business, Simon Fraser University
}

December 2019

\begin{abstract}
This study examines whether and how managerial risk tolerance influences corporate credit ratings. Using information about private pilot licensing status as a proxy for CEO risk tolerance, we find that firms led by pilot CEOs have worse credit ratings after controlling for firm fundamentals, CEO risk-taking incentives, and other CEO characteristics. Path analyses show that risk-tolerant CEOs deteriorate credit ratings by impairing future firm value, exacerbating its volatility, and adversely influencing rating agencies' assessment about the implication of management on credit risk. Also, the negative association between CEO risk tolerance and credit ratings is more pronounced when management plays a more important role in a firm. Overall, our study sheds light on the implications of managerial risk tolerance by documenting its adverse impact on credit ratings.
\end{abstract}

Key Words: Managerial risk tolerance; pilot CEO; corporate credit rating

\footnotetext{
* We thank helpful comments from Sam Bonsall, Mei Cheng, Jinging Zhang, and Ling Zhou. Ray Zhang acknowledges financial support from the Social Sciences and Humanities Research Council of Canada (Grant Number: 430-2019-01095) and the Chartered Professional Accountants of British Columbia. All errors are ours.
} 


\title{
Managerial Risk Tolerance and Corporate Credit Ratings
}

\begin{abstract}
This study examines whether and how managerial risk tolerance influences corporate credit ratings. Using information about private pilot licensing status as a proxy for CEO risk tolerance, we find that firms led by pilot CEOs have worse credit ratings after controlling for firm fundamentals, CEO risk-taking incentives, and other CEO characteristics. Path analyses show that risk-tolerant CEOs deteriorate credit ratings by impairing future firm value, exacerbating its volatility, and adversely influencing rating agencies' assessment about the implication of management on credit risk. Also, the negative association between CEO risk tolerance and credit ratings is more pronounced when management plays a more important role in a firm. Overall, our study sheds light on the implications of managerial risk tolerance by documenting its adverse impact on credit ratings.
\end{abstract}

Key Words: Managerial risk tolerance; pilot CEO; corporate credit ratings 


\section{Introduction}

This study examines the impact of managerial risk tolerance on corporate credit ratings. Since the initial issuance in 1909 , credit ratings have been widely viewed as principal factors reflecting a firm's credit risk, particularly default risk, ${ }^{1}$ by outside stakeholders such as investors, suppliers, customers, financial counterparties, regulators, and public media when evaluating firm credit risk (Kisgen 2007; Becker and Milbourn 2011). The literature has documented that credit ratings have a considerable impact on financial markets (e.g., Hand, Holthausen, and Leftwich 1992; Blume, Lim, and MacKinlay 1998; Ederington and Goh 1998; Campbell and Taksler 2003; Amato and Furfine 2004; Kisgen 2006). In a survey of top executives, Graham and Harvey (2001) document that credit rating is the second-most important factor that firms consider in their financing decisions. Given the importance of credit ratings, it is essential to understand the factors that influence credit ratings. Prior studies have extensively investigated the impact of firm fundamentals and accounting information on credit ratings (Kaplan and Urwitz 1979; Blume et al. 1998). However, prior research has paid little attention to the role of management attributes, particularly managerial risk tolerance, in the rating process. Therefore, we examine whether and, if so, how managerial risk tolerance affects corporate credit ratings.

We focus on managerial risk tolerance because its evaluation is one of the most critical aspects of a credit analyst's job. Standard \& Poor's [S\&P] $(2008,22)$ state that "Management is assessed for its role in determining operational success and also for its risk tolerance." Ganguin and Bilardello $(2005,64)$ point out that "Management should be assessed for its operational and financial successes and failures, but also for the amount of risk it is willing to accept in order to

\footnotetext{
${ }^{1}$ Credit risk consists of two components, i.e., default risk and information risk. The default risk refers to the likelihood that borrowing firms are unable to honor their obligation to pay interests periodically and principal at the maturity, while the information risk, also called estimation risk, refers to the risk associated with estimating default risk (Duffie and Lando 2011; Chiu, Guan and Kim 2018).
} 
deploy its strategies and policies." Several recent studies also stress the importance of understanding managerial risk tolerance to credit rating analysis (e.g., Ham and Koharki 2016; Bonsall, Koharki, and Neamtiu 2017). As debt market intermediaries, credit rating agencies should be particularly sensitive to the implications of managerial risk tolerance since debt market participants have an asymmetric loss function (Beaver et al. 2006; Cantor and Packer 1995; Holthausen and Leftwich 1986; Morgan 2002). For these reasons, we examine the impact of managerial risk tolerance on corporate credit ratings. In particular, our analysis centers on chief executive officers' (CEOs') risk tolerance because they have the most influence over a number of corporate decisions and set the tone of the management team and the organization (e.g., Cheng and Lo 2006; Argenti, Howell, and Beck 2005; Graham, Harvey, and Puri 2013).

CEO risk tolerance could affect corporate credit ratings via several channels: (i) its effect on rating agencies' qualitative analysis of management; and (ii) its effect on the level and the variability of future firm value. ${ }^{2}$ As for the effect on rating agencies' management analysis, rating analysts use a variety of ways, including public meetings and personal calls and visits, to get to know the managers of a rated firm (Ganguin and Bilardello 2005). After getting to know the managers, rating analysts may figure out managerial risk tolerance and perceive risk-tolerant CEOs to be more willing to take on business risk and financial risk and to be less likely to value risk management. Accordingly, they may issue worse ratings to firms with risk-tolerant CEOs. Also, risk-tolerant CEOs are more likely to adopt aggressive corporate policies such as issuing more debts and making more acquisitions (Cain and McKeon 2016), which could in turn increase the variability of future firm value and contributes to worse ratings. In addition, risk-tolerant CEOs might take on overly risky projects and such excessive risk-taking could increase the likelihood of

\footnotetext{
${ }^{2}$ We use the terms "qualitative analysis of management", "management analysis", "management assessment", and "management evaluation" interchangeably in the paper.
} 
failure and bankruptcy (e.g., Koharki, Ringgenberg, and Watson 2019), thereby leading to worse ratings. Given the above impact of risk-tolerant CEOs on rating agencies' assessment of management and the level and the variability of future firm value, we predict that a higher level of CEO risk tolerance is associated with worse credit ratings.

However, one may expect that CEO risk tolerance to have a positive or no association with credit ratings. One possibility is that risk-tolerant CEOs can accept a higher level of risk and hence are less likely to give up projects that are risky but have positive net present value (NPV) (Cain and McKeon 2016), which could increase future firm value and hence improve credit ratings. Another possibility is that the majority of the variation in credit ratings can be explained by firm characteristics so that CEO risk tolerance may not play an important role in explaining the ratings since rating agencies might largely center on firm factors. Given these countervailing arguments, the relation between CEO risk tolerance and credit ratings is ultimately an empirical question.

To examine the relation between CEO risk tolerance and credit ratings, we follow Cain and McKeon (2016) to capture CEO risk tolerance using CEO pilot status and consider CEOs who possess private pilot licenses to be personally more risk-tolerant. ${ }^{3}$ Following Ashbaugh-Skaife, Collins, and LaFond (2006) and Becker and Milbourn (2011), among others, we measure credit ratings based on a firm's long-term issuer ratings assigned by S\&P. Similar to prior studies, we convert letter ratings into numerical scores so that higher values correspond to better ratings.

Using a sample of S\&P 1500 firms over the period 1992-2016, we find that higher CEO risk tolerance is associated with worse credit ratings. This result holds after controlling for firm fundamentals, CEO risk-taking incentives, other CEO characteristics that prior research documents to affect (credit) risk. The result also holds after we remove the aviation industry,

\footnotetext{
${ }^{3}$ As an anecdotal support for our measure, Tesla's CEO Elon Musk possesses pilot license and he is relatively risk tolerant.
} 
eliminate young CEOs, and control for CEO overconfidence, managerial ability, and corporate governance. In addition, we include firm fixed effects and run change analyses to alleviate the concern about time-invariant correlated omitted variables and continue to find a robust negative association between CEO risk tolerance and credit ratings. To further address the endogeneity concern, we also conduct difference-in-difference analyses using a sample of CEO turnovers and its matched control sample and show that ratings get worse (better) after relatively more (less) risk-tolerant CEOs replace existing CEOs. Overall, the evidence suggests that CEO risk tolerance plays a significant role in affecting credit ratings beyond firm fundamentals and other CEO characteristics.

To better understand how CEO risk tolerance adversely affects credit ratings, we next examine the underlying mechanisms through which CEO risk tolerance worsens credit ratings. Using a path analysis, we find that elevated CEO risk tolerance leads to worse ratings through two indirect paths: CEO risk tolerance is associated with a lower level of future firm value and higher volatility of future firm value, which, in turn, results in worse ratings. Higher CEO risk tolerance also contributes to worse ratings through a direct path: when assessing CEOs with high risk tolerance, rating agencies perceive these CEOs as contributing to greater credit risk for their firms. To further corroborate the direct path, we investigate how the relation between CEO risk tolerance and credit ratings varies cross-sectionally after controlling for the indirect paths. We predict and find that the CEO risk tolerance and credit rating relation is more pronounced when management plays a more important role in a firm, i.e., when a firm faces fiercer product market competition, operates in a high-growth industry, and has greater financial constraints.

Our study makes several contributions. First, we extend the literature that explore the factors influencing corporate credit ratings. For instance, Kuang and Qin (2013) find that CEO 
risk-taking incentives are associated with worse ratings, while Koharki, Ringgenberg, and Watson (2019) find the opposite. Different from these two studies that focus on risk-taking incentives that are imposed on CEOs extrinsically through compensation contracts, our study focuses on CEOs' risk-taking preferences as their intrinsic, innate personal traits. We provide evidence that such risktaking preferences are associated with worse ratings after controlling for CEOs' risk-taking incentives stemming from compensation contracts. To the extent that intrinsic risk-taking tendencies cannot be easily alleviated through contracts, the risk tolerance trait can be used by boards of directors to identify CEOs who would potentially lead to worse ratings.

Second, we shed new light on the growing research on rating agencies' qualitative analysis in the rating process. While it is costly to hire rating analysts to perform qualitative analysis, credit rating agencies have always underscored its importance in the rating process (SEC 2011; Cornaggia et al. 2017). Extant literature provides limited evidence on the role of qualitative analysis in the rating process and only recently have researchers started to investigate whether rating agencies take into account key qualitative features, such as managerial ability, and how rating agencies perform qualitative analysis (e.g., Bonsall, Holzman, and Miller 2017; Cornaggia, Krishnan, and Wang 2017; Ham and Koharki 2016; Kraft 2015). We contribute to this emerging literature by examining a new aspect of the qualitative analysis, that is, rating agencies' assessment of managerial risk tolerance, and by documenting its impact on corporate credit ratings.

Third, we contribute to the emerging literature on the effect of individuals' risk attitudes. Prior studies relate individuals' risk attitudes to various legal and economic activities and outcomes (e.g., Collins and Schmidt 1993; Iversen and Rundmo 2002; Graham, Harvey, and Puri 2013; Hvide and Panos 2014). For example, Ehrlich (1973) provides evidence that risk-tolerant individuals commit more crimes than risk-neutral or risk-avoiding individuals. Graham, Harvey, 
and Puri (2013) show that risk-tolerant CEOs are more likely to undertake acquisitions, make a larger number of acquisitions, and receive a larger proportion of compensation in the form of stocks, bonuses, and options, and lower in the form of salary. Pittman, Stein, and Valentine (2019) show that more risk-tolerant audit partners conduct audits of lower quality. We extend this line of literature by examining the impact of risk-tolerant CEOs on corporate credit ratings.

Finally, our study adds to the recent literature on the role of individual managers in a firm. The key argument of this literature is that individual managers influence firm behavior and firm outcomes beyond firm-, industry-, and market-level features. For instance, the seminal paper by Bertrand and Schoar (2003) uses manager fixed effects to provide evidence that managerial "style" influences corporate financing, investment, and organizational practices. However, manager fixed effects capture all managerial time-invariant characteristics and fail to pinpoint specific characteristics of managers. Recent studies start to open "the black box" of manager effect by examining specific managerial traits such as overconfidence (e.g., Malmendier and Tate 2005; Goel and Thakor 2008; Gervais et al. 2011; Hirshleifer et al. 2012; Ben-David et al. 2013; Kim, Wang, Zhang 2016), marital status (Roussanov and Savor 2014), and early life experience (Malmendier, Tate, and Yan 2011; Bernile, Bhagwat, and Rau 2017). We extend this line of research by focusing on managerial risk tolerance, an important managerial trait that has received limited attention from the prior studies.

The remainder of the paper is organized as follows. Section 2 discusses the related literature and develops the testable hypothesis. Section 3 describes the sample and variable construction, and specify empirical models. In Section 4, we report and discuss the main results. Section 5 investigates the underlying mechanisms, and Section 6 concludes the paper. 


\section{Literature Review and Hypothesis Development}

\subsection{The determinants of corporate credit ratings}

Existing literature has documented various factors that influence corporate credit ratings. Early studies focus on the effect of firm fundamentals such as size, performance, leverage, and interest coverage (e.g., Horrigan 1966; Kaplan and Urwitz 1979; Blume et al. 1998). Later, researchers expand their focus to other firm-specific determinants of credit ratings, including accounting quality (e.g., Alissa, Bonsall, Koharki, and Penn 2013; Jung, Soderstrom, and Yang 2013) and corporate governance (Ashbaugh-Skaife, Collins, and LaFond 2006). Recently, studies have started to explore the impact of CEO characteristics on credit ratings. For instance, Kuang and Qin (2013) and Koharki, Ringgenberg, and Watson (2019) document that CEO risk-taking incentives stemming from compensation contracts are related to ratings. Bonsall, Holzman, and Miller (2017) and Cornaggia, Krishnan, and Wang (2017) argue that rating agencies qualitatively assess management and show that managerial ability is associated with better ratings.

\subsection{Implication of individual risk attitude}

Individuals' risk attitudes have received considerable attention from researchers in psychology and economics. One line of research links an individual's risk appetite to their legal infractions (e.g., Collins and Schmidt 1993; Iversen and Rundmo 2002). For instance, Ehrlich (1973) provides evidence that risk-tolerant individuals commit more crimes than risk-neutral or risk-avoiding individuals. These individuals either underestimate the possibility of being detected (Garoupa 2003; Palmer and Hollin 2004; Eide, Rubin, and Shepherd 2006; Walters 2009) or can figure out ways to defend the negative ramifications in case they are caught (Becker 1968; Ehrlich 1973). Prior research also connects risk tolerance with less severe legal infractions such as traffic 
violations (Gottfredson and Hirschi 1990; Junger et al. 2001; Fisman and Miguel 2007; Davidson et al. 2015; Castillo-Manzano, Castro-Nuño, and Fageda 2015).

Another line of research relates individuals' risk attitudes to various economic activities and outcomes. Graham, Harvey, and Puri (2013) administer psychometric tests to CEOs and provide evidence that risk-tolerant CEOs are more likely to undertake acquisitions and make a large number of acquisitions. They also show that risk-tolerant CEOs tend to receive a larger proportion of compensation in the form of stocks, bonuses, and options, and a lower proportion in the form of salary. Hvide and Panos (2014) find that risk-tolerant individuals are more likely to start up a firm as entrepreneurs, but the firms that they start up perform worse as reflected in lower sales and lower return on assets. Hrazdil et al. (2019) show that auditors charge higher audit fees for firms with risk-tolerant CEOs due to their concern about these CEOs' risk-taking. Pittman, Stein, and Valentine (2019) indicate that more risk-tolerant audit partners conduct lower-quality audits and charge lower audit fees.

Recent studies tie piloting to individuals' risk tolerance and examine its implications on corporate policies and outcomes. Cain and McKeon (2016) document that pilot CEOs are associated with higher firm risk and the elevated firm risk arises from higher leverage and more acquisition activities that these CEOs undertake. Sunder, Sunder, and Zhang (2017) argue that pilot CEOs are prone to sensation seeking and combine risk tolerance with a desire for novel experiences; hence, they are likely to be more successful in innovations. They provide evidence supporting this argument - CEO piloting is associated with not only higher quantity of patents and citations but also greater innovation effectiveness and more diverse and original patents. Our paper directly relates to this recent stream of research and uses CEO pilot status to examine the implications of managerial risk tolerance, particularly CEO risk tolerance, for firm credit ratings. 


\subsection{Hypothesis development}

CEO risk tolerance could affect firm credit ratings via several effects: (i) its effect on rating agencies' qualitative analysis of management; and (ii) its effect on the level of future firm value and the variability of future firm value. As for the first effect, rating agencies emphasize the importance of qualitative analysis of management in the rating process and take into account managerial risk tolerance when assessing management (Moody's Investors Service [Moody's] 2006; S\&P 2008). For instance, S\&P $(2008,22)$ explicitly state that "Management is assessed for its role in determining operational success and also for its risk tolerance". Ganguin and Bilardello $(2005,64)$ also point out that "Management should be assessed for its operational and financial successes and failures, but also for the amount of risk it is willing to accept in order to deploy its strategies and policies." To evaluate managerial risk tolerance, rating analysts use a variety of ways to get to know the rated firms' managers. They are required to attend many public meetings, including quarterly and periodic financial analyst meetings and teleconferences, the annual shareholder meetings, and the occasional road show before bond and stock offerings (Ganguin and Bilardello 2005). Attending these public meetings provides rating analysts an opportunity to qualitatively assess management, particularly, its innate attributes such as risk tolerance. Rating analysts could also personally call or visit firm managers to further examine their strategies and prospects, but also to better evaluate management itself (Ganguin and Bilardello 2005).

If rating analysts consider managers to be risk-tolerant after getting to know them, they could perceive these managers as leading to higher credit risk. Among the top management team, CEOs play the most prominent role in setting corporate strategies and policies; hence, we posit that rating analysts would place a significant emphasis on CEO risk tolerance. First, rating analysts could perceive risk-tolerant CEOs as being more willing to accept a higher level of risk both in the 
form of business risk and financial risk. ${ }^{4}$ Second, rating analysts could perceive risk-tolerant CEOs as being more likely to place a lower importance on risk management and hence exert less effort and deploy fewer resources to risk management. For instance, risk-tolerant CEOs may be less prone to use derivatives to manage the exposure to foreign exchange or commodity price movements, which could result in higher earnings and cash flow volatility. For these reasons, rating analysts could view risk-tolerant CEOs contributing to higher credit risk and hence assign worse ratings for firms that are run by these CEOs.

As for the second effect mentioned earlier, CEO risk tolerance could influence firm ratings through its effect on the level of future firm value. Risk-tolerant CEOs might be very aggressive in taking on risky projects to the extent that "the CEOs' preferences have crossed the threshold for risk neutrality into the risk-seeking domain" (Cain and McKeon 2016, 156). Such excessive risktaking could increase the likelihood of failure and bankruptcy (e.g., Koharki, Ringgenberg, and Watson 2019). Also, the excessive risk-taking is an important mechanism that leads stock prices to crash (e.g., Bebchuk 2009; Chen, Kim, Li, and Liang 2018; Kim, Zhang, and Zhong 2019). As a result, firms with risk-tolerant CEOs are likely to have a lower level of future firm value and such firms are more likely to fail to service debt obligations (failure to pay interests in each period and principal at the maturity) in the future, which could in turn contribute to worse ratings.

In addition, CEO risk tolerance could affect firm credit ratings through its effect on the variability of future firm value. Specifically, risk-tolerant CEOs may make more risky investments such as investments in innovation projects (Sunder, Sunder, and Zhang 2017), which could result in more variable future firm value (Bonsall, Holzman, Miller 2017). Further, Cain and McKeon (2016) show that firms run by risk-tolerant CEOs take on more debt and undertake more

\footnotetext{
${ }^{4}$ Ganguin and Bilardello $(2005,76)$ state that “... the analyst's job is to determine how much business and financial risk management is willing to accept and how much it employs."
} 
acquisition activities, thereby experiencing higher equity return volatility. As the variability of future firm value increases, whether borrowers can fulfill their debt obligations in the future becomes more uncertain, thereby leading to worse credit ratings.

Dawing on the above discussions, we predict that CEO risk tolerance leads to worse credit ratings by adversely influencing rating agencies' assessment of the implication of management for credit risk, increasing the variability of future firm value, and reducing the level of future firm value. Thus, we propose the following hypothesis, stated in alternative form:

Hypothesis: $C E O$ risk tolerance is inversely associated with corporate credit ratings.

However, we acknowledge that CEO risk tolerance may not be associated with worse credit ratings for the following reasons. First, CEO risk tolerance could be positively associated with credit ratings. The agency theory argues that risk-averse managers could incur agency costs on shareholders in that they give up risky projects with positive NPV (e.g., Jensen and Meckling 1976). Since risk-tolerant CEOs can accept a higher level of risk, they are less likely to drop projects that are risky but have positive NPV (Cain and McKeon 2016). Given that managers tend to take too little risk in reality and often do not select all projects with positive NPV (Gormley and Matsa 2016; Graham 2017), risk-tolerant CEOs have potential to increase future firm value. With higher firm value associated with risk-tolerant CEOs, their companies are less likely to miss principal and interest payments (Bonsall, Holzman, and Miller 2017), which in turn reduces credit risk and contributes to better ratings. Moreover, risk-tolerant CEOs could be associated with better innovation outcomes (Sunder et al. 2017), and selling collateralized innovation products (e.g., patents) may help secured creditors recover more in the bankruptcy process (Ma, Tong, and Wang 2019), which could also lead to better ratings. Second, CEO risk tolerance may not be associated with credit ratings. This is because rating agencies may largely focus on firm (rather than 
management) factors; accordingly, firm characteristics could largely explain the variation in credit ratings and managerial risk tolerance may not have a material impact on ratings beyond firm fundamentals.

\section{Sample and Research Design}

\subsection{Sample and data}

We draw an initial sample of CEOs from the ExecuComp database during the period 1992 through 2016. Our sample starts with 1992 because ExecuComp begins its data coverage in 1992. To identify whether a CEO holds a pilot license, we search for the CEO's name at the Federal Aviation Administration Airmen Certification database (FAA). ${ }^{5}$ If there is no match for a given name in the FAA's database, we code this observation as a non-pilot and do not conduct further validation. If there are at least one name match in the FAA's database, we follow Cain and McKeon (2016) to manually validate and cross-check the name match by supplementing information about a CEO's birth date and home address from Bloomberg, LexisNexis, and other public record searches. A CEO is classified as a non-pilot CEO if i) his/her name does not show up on the FAA website, or ii) there is a name match on the FAA website but the CEO's birth date or home address does not match the corresponding record on the FAA website. ${ }^{6}$

We obtain financial data and S\&P's long-term issuer credit ratings from Compustat, stock market data from the Center for Research on Security Prices (CRSP), CEO compensation and characteristics data from ExecuComp, and CEO military background data from BoardEx. After further requiring the data availability for variables used in the main empirical analyses, we obtain

\footnotetext{
5 Available at https://amsrvs.registry.faa.gov/airmeninquiry/.

${ }^{6}$ For any CEO who has a name match on the FAA website but for whom we cannot find birth date or home address information in order to cross-check the name match, we delete the observation.
} 
a final sample of 13,020 firm-year observations that consist of 142 unique pilot CEOs and 2,432 non-pilot CEOs.

\subsection{Measure of CEO risk tolerance}

We capture CEO risk tolerance based on whether a CEO holds a pilot certificate because piloting reflects an individual's inherent risk tolerance (Cain and McKeon 2016). Extant research provides evidence that operating a small aircraft is in line with higher health risk as reflected in elevated mortality rates (McFall 1992; Cain and McKeon 2016). Hence, it is reasonable to use a CEO's pilot status to capture CEO risk tolerance. If a CEO holds a pilot license, we consider him/her to be more risk-tolerant; otherwise, we consider him/her being less risk-tolerant. Empirically, we define Pilot CEO as an indicator variable that takes the value of one if a firm's CEO holds a pilot certificate and zero otherwise.

\subsection{Measure of corporate credit rating}

Following prior research (e.g., Ashbaugh-Skaife et al. 2006; Bonsall et al. 2017), we use S\&P's long-term issuer credit rating to capture corporate credit rating. We transform these letter ratings into numerical scores using two approaches. First, we follow Ashbaugh-Skaife, Collins, and LaFond (2006) to construct Ratingl by translating the letter ratings into seven numeric values between one and seven. Second, we follow Becker and Milbourn (2011) to construct Rating2 by converting the letter ratings into finer numerical scores, with the highest numerical rating of 28 being assigned to the AAA letter rating and the lowest numerical rating of 4 being assigned to the C letter rating. A higher Rating1 or Rating2 implies better credit ratings.

\subsection{Empirical model}

To test our hypothesis on the relation between CEO risk tolerance and corporate credit ratings, we use ordinary least squares (OLS) regressions to estimate the following model: 


$$
\text { Rating }=\alpha_{0}+\beta_{1} \text { Pilot CEO }+\sum \beta_{\mathrm{k}} \text { Controls }+ \text { Industry FE }+ \text { Year FE }+\varepsilon
$$

where the dependent variable Rating is either Rating1 or Rating2, while the key independent variable is Pilot $C E O$. Both rating variables and Pilot $C E O$ are defined as above. To address the concern about potential time-series and cross-sectional dependence in the data, we report HuberWhite standard errors corrected for firm-level clustering (Petersen 2009; Cameron et al. 2011). Our hypothesis predicts a negative association between Pilot CEO and credit ratings, implying that $\beta_{1}$ is negative.

To separate the effect of CEO risk tolerance on credit ratings from the effects of other variables, we include a set of control variables that prior research documents to affect credit risk and credit ratings (e.g., Horrigan 1966; Kaplan and Urwitz 1979; Boardman and McEnally 1981; Lamy and Thompson 1988; Ziebart and Reiter 1992; Ashbaugh-Skaife et al. 2006; Cain and McKeon 2016). We use leverage (Leverage), return on assets (ROA), interest coverage (Int_cov), existence of loss (Loss), and presence of subordinated debt (Subord) to control for default risk. The inclusion of ROA, which is based on earnings, controls for not only performance but also earnings management correlated with performance (Roychowdhury 2006; Lee 2012). Loss firms and firms with higher leverage, smaller interest coverage, and subordinated debt face higher default risk. We also control for firm size (Size) because larger firms face lower credit risk. Since firms with more tangible assets tend to have higher liquidation values and lower agency costs of debt (Harris and Raviv 1990; Williamson 1988), we control for asset tangibility (Cap_inten). Additionally, we include stock return volatility ( $L o g \mathrm{Vol})$ measured by the variance of daily stock return as it is positively associated with credit risk (Bonsall et al. 2017).

We also control for several CEO characteristics including age (Age), tenure (Tenure), military experience (Military), and risk-taking incentives (LogVega and LogDelta). Similar to Cain 
and McKeon (2016), we expect companies with older and longer-tenured CEOs to have lower firm risk, as older CEOs tend to be more risk-averse and longer-tenured CEOs could operate the firm in a more stable manner. CEOs with a military background may inherently have a higher tolerance of risk or increase their risk tolerance during the period of military service and hence could relate to higher firm risk (Cain and McKeon 2016). CEO risk-taking incentives extrinsically imposed through the compensation contracts are related to firm risk and credit rating as well (e.g., Coles, Daniel, and Naveen 2006; Kuang and Qin 2013; Koharki, Ringgenberg, Watson 2019). Appendix provides more detailed definitions of all these variables.

\section{Main Results}

\subsection{Descriptive statistics}

Panel A of Table 1 presents descriptive statistics for corporate credit ratings, CEO pilot status, and control variables used in the analyses. The credit rating variables, Rating 1 and Rating2, have a mean value of 3.809 and 18.413, respectively, which resemble those presented in Ashbaugh-Skaife et al. (2006) and Becker and Milbourn (2011). These statistics suggest that corporate rating is on average around BBB-. The mean value of Pilot CEO is 0.056, indicating that about 5.6 percent of the firm-year observations have a pilot CEO. The average firm in our sample has total assets amounting to $\$ 5.335$ billion, a leverage of $0.313, R O A$ of 0.039 , gross PPE representing 59.3 percent of total assets, and an interest coverage ratio of 12.744 . About 7.2 percent of the firm-year observations report a loss in the current fiscal year, while 31.6 percent have subordinated debts. Turning to the CEO characteristics, on average, a CEO is 55.6 years old, and has served in the CEO position for 5.6 years. The mean value of LogVega and LogDelta is 4.044 and 5.513, respectively, similar to those reported in Chen et al. (2015). About 9.7 percent of the 
observations have CEOs with military experience. Overall, the descriptive statistics of the variables used in this study are comparable to those from prior studies (e.g., Ashbaugh-Skaife et al. 2006; Cain and McKeon 2016; Zhang 2018).

Panel B of Table 1 presents the results of the univariate tests for the mean and median differences between firms led by pilot CEOs and those led by non-pilot CEOs. Firms led by pilot CEOs have lower (i.e., worse) ratings in terms of both mean and median values than firms led by non-pilot CEOs. Moreover, these differences are statistically significant at the $1 \%$ level. Though only suggestive of the underlying relation, this result is in line with the prediction in our hypothesis. Also, firms led by pilot CEOs are larger, have higher leverage, higher capital intensity, higher variance in current firm value, lower $R O A$, and lower interest coverage, and are more likely to have subordinated debt. Compared to non-pilot CEOs, pilot CEOs are younger, have longer tenure, are more likely to have military experience, and have a compensation package more sensitive to stock price changes. Collectively, the above comparisons suggest that firms led by pilot CEOs and those led by non-pilot CEOs differ along multiple firm features and CEO characteristics, pointing to the need to control for these differences in multivariate analyses when examining the relation between pilot CEOs and credit ratings.

Table 2 reports the correlations among corporate ratings, CEO pilot status, and control variables used in the multivariate analyses. The lower (upper) triangle reports the Pearson (Spearman) correlation statistics. Since the Spearman correlations are similar to the Pearson correlations, we only discuss the Pearson correlations below for brevity. Our primary variable of interest, Pilot $C E O$, is inversely related to both Rating 1 and Rating2, providing some preliminary support for our hypothesis. Pilot CEO is also negatively associated with ROA, Int_cov, and Age, but positively correlated with Size, Leverage, Cap_inten, Subord, Tenure, Military, LogDelta, and 
LogVol. The correlation results are consistent with the univariate comparison results reported in Panel B of Table 1.

\subsection{Baseline results}

Table 3 presents the results of various regressions of credit ratings on Pilot CEO and control variables. Columns 1 and 2 only include the Pilot CEO dummy and industry and year fixed effects, with the dependent variable being Rating1 and Rating2, respectively. In both columns, the coefficient on Pilot CEO is significantly negative at the $1 \%$ level, supporting the hypothesis that higher CEO risk tolerance is associated with worse credit ratings. Given that no control variables are included in columns 1 and 2, it is possible that the coefficients in these two columns are dubious, as they could be driven by correlated omitted variables. To rectify this, in columns 3 and 4 we include LogVega and LogDelta to control for CEO risk-taking incentives stemming from compensation contracts and find similar results. In columns 5 and 6, we further control for a set of firm characteristics (Size, Leverage, ROA, Loss, Cap_inten, Int_cov, Subord, LogVol) that are shown to be associated with credit ratings. We find that the coefficients on Pilot CEO remain significantly negative, regardless of the rating variables used. In columns 7 and 8 , we include three additional CEO characteristics (Age, Tenure, and Military) and continue to find similar results. Overall, these results suggest that CEO risk tolerance adversely influences corporate credit rating beyond firm fundamentals, CEO risk-taking incentive, and other CEO characteristics.

The impact of Pilot CEO on credit rating is economically significant as well. Based on the result in column 8 , we find that having a pilot CEO is associated with a credit rating that is 0.684 worse than having a non-pilot $\mathrm{CEO}$, which is equivalent to $3.7 \%$ of the mean value of credit rating. To place the economic significance in a context, we compare the effect of pilot CEOs with that of other firm-specific and CEO-specific determinants of credit ratings. For example, interest coverage 
has a significant impact on credit rating based on both theory and evidence - the coefficient on Int_cov in column 8 is 0.027 . Given that the standard deviation of Int_cov is 19.407 , this result implies that a one-standard-deviation increase in Int_cov would increase credit rating by 0.524 (i.e., $0.027 \times 19.407$ ), equivalent to $2.85 \%$ of the mean value of credit rating. Thus, pilot CEOs seem to have a more economically significant impact on credit rating than moderate changes in firm characteristic such as Int_cov.

The results on the control variables are generally consistent with those of prior research (e.g., Ashbaugh-Skaife et al. 2006; Bonsall et al. 2017; Cain and McKeon 2016; Koharki, Ringgenberg, Watson 2019; Zhang 2018). As for firm characteristics, both Rating1 and Rating2 are positively associated with firm size (Size), return on asset (ROA), capital intensity (Cap_Inten), interest coverage (Int_cov), yet negatively associated with leverage (Leverage), the presence of subordinated debt (Subord), and stock return volatility (LogVol). Among the CEO characteristics, a firm's credit rating improves when the change in CEO wealth is more sensitive to firm risk (LogVega) but worsens when the change in CEO wealth is more sensitive to firm value (LogDelta).

\subsection{Robustness checks}

In this subsection, we conduct several tests to ensure that the preceding results of the negative association between pilot CEOs and credit ratings are robust to an alternative regression procedure and alternative subsamples.

\subsubsection{Alternative regression procedure}

So far, we use OLS procedure to estimate various forms of our baseline regression in equation (1). The OLS regression treats every rating scale as equal. However, ratings may not work this way given their ordinal nature (Becker and Milbourn 2011). To address this concern, we run an ordered logit regression, which permits the rating variables to change with different rating 
scale and hence uses data more efficiently (though it may be less robust to some econometric issues than an OLS regression). Columns 1 and 2 of Table 4 present the re-estimated results for models (7) and (8) in Table 3, using the ordered logit regression. ${ }^{7}$ As shown in both columns, we find a significant and negative coefficient on Pilot CEO, irrespective of whether Rating1 or Rating2 is used as the dependent variable. These findings suggest that our baseline results of a negative association between pilot CEOs and credit rating are robust to the use of an alternative regression procedure, lending further support to our hypothesis.

\subsubsection{Alternative samples}

We also reexamine the relation between pilot CEO and credit rating using alternative samples to ensure the robustness of our baseline results to the use of alternative samples. First, one concern is that firms in airline-related industries are more prone to hiring CEOs who have flying experience. While this effect is unlikely to drive the negative relation between Pilot CEO and credit rating that we have documented so far, we follow Cain and McKeon (2016) and Sunder et al. (2017) to remove firms in the aviation industry and then re-estimate equation (1). As shown in columns 3 and 4 of Table 4, the coefficients on Pilot CEO remain negative and significant at the $1 \%$ level in both columns.

Second, as we construct our sample of pilot CEOs by building on the sample of Cain and McKeon (2016) and extending it to more recent years, one concern is that more CEOs are picking up the flying hobbies in recent years and our results are driven by more recent years (i.e., after 2009) or some measurement error in our data collection process. Although there is no academic or anecdotal support for this claim (in particular, measurement error would bias against finding results), we rerun the main regressions by removing the recent years from the sample, and instead,

\footnotetext{
${ }^{7}$ We use models (7) and (8) in Table 3 as our baseline models throughout the various analyses.
} 
using the Cain and McKeon (2016)'s sample. As reported in columns 5 and 6 of Table 4, the coefficients on Pilot $C E O$ continue to be significantly negative. Collectively, the evidence suggests that our results remain unchanged when we use alternative samples that exclude firms in the aviation industry or observations in recent years.

\subsection{Alternative explanations}

Next, we address potential alternative explanations for the negative association between pilot CEOs and corporate credit ratings. First, one may be concerned that younger CEOs are more risk-tolerant and that our baseline results are driven by younger CEOs. To address this concern, we control for CEO age as well as CEO tenure throughout the analyses. To further alleviate this concern, we exclude firm-year observations with the 20 percent youngest CEOs in our sample. Columns 1 and 2 of Table 5 report the results. The coefficients on Pilot CEO in both columns remain negative and significant at the $1 \%$ level, irrespective of whether Rating1 or Rating 2 is used as the dependent variable. ${ }^{8}$

Second, overconfident CEOs may have a higher level of risk tolerance and firms with overconfident CEOs are likely to be rated unfavorably. This is because overconfident managers tend to pursue value-decreasing strategies (e.g., Cain and McKeon 2016). To alleviate this concern, we follow Dezsö and Ross (2012) to construct CEO overconfidence (CEO Overconfidence) and include it as an additional control. Appendix provides more details on the definition of this variable. As shown in columns 3 and 4 of Table 5, the coefficients on Pilot CEO remain negative and significant at the $1 \%$ level in both columns.

\footnotetext{
${ }^{8}$ As an additional sensitivity analysis, we alternatively remove firm-years with the 50 percent youngest CEOs in the sample and find that the coefficient on Pilot CEO is negative and significant at the 5\% level, regardless of the rating variables used.
} 
Third, one may argue that pilot CEOs have low ability, which in turn leads to worse ratings. Although managerial ability is positively associated with credit ratings (Bonsall et al. 2017; Cornaggia et al. 2017), it is ex ante unclear whether and how managerial ability is related to managerial risk tolerance. ${ }^{9}$ Nonetheless, we control for Managerial Ability (managerial ability score constructed by Demerjian et al. 2012) in the main regressions. Columns (5) and (6) of Table 5 report the results. The coefficient on Pilot CEO remains significant and negative, regardless of the rating definitions.

Lastly, poorly governed firms might recruit CEOs with high risk tolerance and meanwhile receive unfavorable ratings. Even though weak governance is shown to be associated with worse ratings (Ashbaugh-Skaife et al. 2006), we are not aware of any theory or evidence that relates corporate governance to CEOs' inherent risk tolerance. Nevertheless, we augment the baseline models with four governance attributes: Board Size (Board Size), Board Independence (Board Independence), CEO Duality (Duality), and the voting power of insider directors (Insider Voting Power). ${ }^{10}$ Columns 7 and 8 of Table 5 report the results of these analyses. The coefficients on Pilot CEO continue to be significant and negative, irrespective of whether RATING1 or RATING2 is used as the dependent variable.

\subsection{Addressing potential endogeneity}

In our setting, potential endogeneity may arise from correlated omitted variables (i.e., certain firm-specific or CEO-specific omitted factors may be correlated with both CEO risk tolerance and credit rating) or reverse causality (i.e., firms with poor ratings are more likely to hire

\footnotetext{
${ }^{9}$ Given that pilot CEOs are associated with better innovation outcomes (Sunder et al. 2017), it is possible that pilot CEOs have higher ability. In this case, we should observe better ratings, rather than worse ratings, for firms with pilot CEOs. Hence, it is unlikely that the alternative explanation of managerial ability drives out results.

${ }^{10}$ As additional robustness check, we also include additional governance attributes such as the independence of audit committee, nomination committee, compensation committee, the untabulated results remain qualitative similar.
} 
risk-tolerant CEOs). We address this concern using multiple approaches. First, we control for several firm-level and CEO-level variables that prior studies document to be associated with (credit) risk and credit ratings such as leverage and CEO risk-taking incentives. Second, we conduct a set of cross-sectional analyses in Section 5 to test whether our results are consistent with additional predictions regarding the situations in which CEO risk tolerance should have a different effect on credit ratings. The cross-sectional analyses could help assuage the concern about correlated omitted variables, because, for an omitted variable to explain the cross-sectional results, it has to influence both CEO risk tolerance and credit rating in a given manner conditional on a partitioning variable. To further alleviate the endogeneity concern, we use three additional approaches as discussed below.

\subsubsection{Firm fixed effects regressions}

While we have included various control variables in our regressions, it is still possible that our analyses omit some unobservable time-invariant, but firm-specific, variables that are correlated with both CEO risk tolerance and credit ratings. To alleviate this concern, we re-estimate our baseline regressions in columns (7) and (8) of Table 3 using firm fixed effects in lieu of industry fixed effects and present the results in Panel A of Table 6. The coefficients on Pilot CEO remain negative and significant at the $1 \%$ level in both columns (1) and (2) where Rating1 and Rating2 are, respectively, used as the dependent variable. These results suggest that our baseline results of a negative association between CEO risk tolerance (i.e., one of CEO's innate traits) and credit ratings are unlikely to be driven by the time-invariant, but firm specific, correlated omitted variables. $^{11}$

\footnotetext{
${ }^{11}$ To further check whether our results are driven by time-invariant omitted variables, we alternatively use the first difference specification in testing the impact of CEO risk tolerance on credit rating. That is, we take the difference between the current value and the lagged value for each variable in equation (1) and then re-estimate equation (1) using these change variables. The untabulated results are qualitatively similar to those reported in the paper.
} 


\subsubsection{Difference-in-differences analyses}

While controlling for firm and year fixed effects effectively accomplishing a differencein-differences estimation (e.g., DeFond and Lennox 2016; Carpenter and Dobkin 2011), we still conduct difference-in-difference analyses using a reduced sample of firms that experience CEO turnovers and their matched control firms to further address the endogeneity concern. Specifically, we first identify a treatment sample of firms with CEO turnovers that lead to a change in pilot status (i.e., switching from a non-pilot CEO to a pilot CEO and vice versa) during the sample period. When a firm has multiple CEO turnovers during the sample period, we only include the first one. Then we select the control sample based on ex ante probabilities of CEO turnover from firms that have never had a pilot CEO over the sample period. We estimate ex ante probabilities of CEO turnover using a logit model with all the control variables in model (7) of Table 3 as the explanatory variables. Next, we construct the control sample by using the nearest neighbor method to pick firms with the propensity score closest to that of the treatment firms within the same industry.

Using this matched sample, we estimate the following OLS model:

$$
\text { Rating }=\beta_{0}+\beta_{1} \text { Post } \times \text { Turnover }+\beta_{2} \text { Post }+\beta \mathrm{k} \text { Controls }+ \text { Firm FE }+ \text { Year FE }+\varepsilon \text { (2) }
$$

In this equation, Post is an indicator variable that takes one for the two years following a CEO turnover and zero for the two years before the CEO turnover, where CEO turnover refers to actual CEO turnover for treatment firms and pseudo CEO turnover for control firms identified based on their matched treatment firms. Turnover is an indicator that takes the value of positive (negative) one if a firm switches from a non-pilot CEO to a pilot CEO (from a pilot CEO to a non-pilot CEO) one or two years ago and zero otherwise. Other variables are defined previously in detail (see Appendix). Note that Turnover is excluded in the regression due to its collinearity with firm fixed 
effects. The variable of interest is the two-way interaction term Post $\times$ Turnover. Given the hypothesis that CEO risk tolerance is negatively associated with credit ratings, we expect the coefficient on this interaction term to be negative.

Panel B of Table 6 reports the results. Column (1) uses Ratingl as the dependent variable, while column (2) uses Rating2 as the dependent variable. In both columns, the coefficient on Post $\times$ Turnover is significant and negative, suggesting that as a firm changes from a non-pilot CEO to a pilot CEO (from a pilot CEO to a non-pilot CEO), its credit rating worsens (improves), relative to a firm in the control sample (that does not change their CEOs' pilot status). These results provide additional support that our baseline results on CEO risk tolerance and credit ratings are unlikely to be driven by the correlated omitted variables and other endogeneity concerns.

\subsubsection{Inclusion of lead and lag indicators for pilot CEOs}

One may argue that firms with poor ratings are more likely to hire risk-tolerant CEOs to improve firm performance and obtain better ratings in the future. This possibility is remote, if not impossible for two reasons. First, although Sunder et al. (2017) document that pilot CEOs are associated with better innovation outcomes, no prior studies provide evidence that CEO risk tolerance is related to higher firm performance. Second, rating consideration should not be an important factor in the recruitment of top executive like CEOs and no theory or evidence suggests that risk-tolerant CEOs have potential to help improve firm ratings. Nonetheless, we further address this concern for reverse causality by using an approach modified from Bertrand and Mullainathan (2003) and Giroud and Mueller (2010).

Specifically, we replace Pilot $C E O$ in the main regression with five indicator variables: Before $^{-2}$, Before $^{-1}$, Before $^{0}$, After $^{l}$, and After $^{2+}$. Before $^{0}$ is an indicator variable that equals positive (negative) one if a firm switches to (switches away from) a pilot CEO this year and zero otherwise. 
Before $^{-1}$ and Before ${ }^{-2}$ are indicators that equal positive (negative) one if a firm switches to (switches away from) a pilot CEO in one year from now and two years from now, respectively. After $^{l}$ and $A f t e r^{2+}$ are indicators that equal positive (negative) one if a firm switches to (switches away from) a pilot CEO one year ago and two years ago, respectively. If a pilot (non-pilot) CEO gets hired due to the existing poor (good) ratings, then we should observe a rating "effect" even prior to the start of a pilot (non-pilot) CEO's contract. Specifically, if the coefficient on Before ${ }^{-2}$ or Before $^{-1}$ is negative and significant, then this would be indicative of reverse causality.

Panel C of Table 6 reports the results. The coefficients on Before ${ }^{-2}$ and Before ${ }^{-1}$ are small and insignificant, while the coefficients on Before ${ }^{0}$, After $^{l}$, and After ${ }^{2+}$ are large and significantly negative. These results suggest that there seems to be no "effect" of pilot (non-pilot) CEOs before they start their position, which confirms that the causation goes from pilot (non-pilot) CEOs to credit rating, rather than the other way around. The coefficient on Before ${ }^{0}$ is smaller than the coefficients on both $A f t e r^{l}$ and After ${ }^{2+}$, again providing support for the causal interpretation of our results. In addition, the insignificant coefficients for Before ${ }^{-1}$ and Before $^{-1}$, along with the significant coefficients for Before ${ }^{0}$, After $^{l}$, and After ${ }^{2+}$, also suggest that the parallel trend assumption is not violated. ${ }^{12}$

\section{Underlying Mechanisms}

Our results thus far are in line with the hypothesis that higher CEO risk tolerance is associated with worse credit ratings, even after taking into account potential endogeneity. In this section, we explore the underlying mechanisms through which CEO risk tolerance affects a firm's

\footnotetext{
${ }^{12}$ The parallel trend assumption is a key assumption underlying the difference-in-difference analysis. It requires that the treatment and control samples have the same over-time trend unless there is an intervention, like CEO turnover in this study, during the sample period. The multi-period dynamic analysis as presented in Panel C of Table 6 is also widely used in the literature to ensure no violation of this assumption (Bertrand and Mullainathan 2003).
} 
credit rating. As discussed in Section 2, CEO risk tolerance can affect corporate credit ratings via its effect on rating agencies' qualitative analysis of management as well as its effect on the level and the variability of future firm value. We explore these mechanisms using a path analysis and a set of cross-sectional analyses as discussed below.

\subsection{Path analysis}

Path analysis utilizes a structural equation model to address the question of how a source variable (Pilot CEO) influences an outcome variable (Rating1 or Rating2) by decomposing the correlation between the two into the direct and indirect paths through mediating variables (Baron and Kenny 1986). In our setting, we expect rating agencies' qualitative analysis of management to be a direct path through which Pilot $C E O$ influences rating variables; we expect both the level and the variability of future firm value to be indirect paths (mediating variables). To implement the path analysis, we use one-year-ahead Tobin's Q (Future_TobinQ) to capture the level of future firm value and one-year-ahead stock return volatility (Future_Vol) to capture the variability of future firm value. ${ }^{13}$ Following prior research that uses path analysis (Pevzner, Xie, and Xin 2015; DeFond, Lim, and Zang 2016), we estimate the following models:

$$
\begin{aligned}
& \text { Rating } 1 \text { (or Rating } 2)=\beta_{0}+\beta_{1} \text { Pilot CEO }+\beta_{2} \text { Future_Tobin } Q+\beta_{3} \text { Future_Vol } \\
& +\sum \beta_{k} \text { Controls }+ \text { Industry FE }+ \text { Year FE }+\varepsilon \\
& \text { Future_Tobin } Q=\alpha_{0}+\alpha_{1} \text { Pilot } C E O+\text { Industry FE }+ \text { Year FE }+\mu \\
& \text { Future_Vol }=\delta_{0}+\delta_{1} \text { Pilot } \mathrm{CEO}+\text { Industry FE }+ \text { Year FE }+\Psi
\end{aligned}
$$

In the above equations, control variables are from model (7) of Table 3 and all the variables are defined as before or in the Appendix. The path coefficient $\beta_{1}$ is the magnitude of the direct path from the source variable Pilot CEO to the outcome variable, Rating1 or Rating2, while the path

\footnotetext{
${ }^{13}$ We use stock return volatility as measured by natural log of standard deviation of daily stock return over a fiscal year to capture the variability of future firm value, because it is difficult to obtain daily measure of Tobin's Q and calculate its standard deviation in a fiscal year.
} 
coefficient $\alpha_{1} \times \beta_{2}\left(\delta_{1} \times \beta_{3}\right)$ is the magnitude of the indirect path from Pilot CEO to rating variables mediated through the level of future firm value (the variability of future firm value). We estimate the significance of the indirect effect, using the Sobel (1982) test statistics. Figure 1 illustrates the direct and indirect paths for the above models.

Table 7 presents the results of the path analyses using Ratingl and Rating2 as the rating variable, respectively. Since the results for Ratingl and Rating2 are similar, we only discuss the results for Rating2 in detail as reported in column 2. The direct path coefficient between Pilot CEO and Rating2 [ $p($ Pilot $C E O$, Rating 2$)=-0.688]$ is significantly negative at the $1 \%$ level. The path coefficient between Pilot CEO and Future_TobinQ $[p($ Pilot CEO, Future_TobinQ $)=-0.184]$ is significantly negative at the $1 \%$ level, suggesting that pilot CEOs are associated with lower future firm value than non-pilot CEOs. The path coefficient between Future_TobinQ and Rating2 $[p($ Future_TobinQ, Rating2 $)=0.628]$ is significant and positive at the $1 \%$ level, indicating that future firm value is positively related to credit ratings. The total mediated path for the level of future firm value $[p($ Pilot CEO, Future_TobinQ $) \times p($ Future_TobinQ, Rating2 = -0.115] is significantly negative at the $5 \%$ level. This result implies that the proportion of the total effect of Pilot CEO on Rating2 that is attributed to the level of future firm value is about 12.6 percent [=$0.115 /(-0.688-0.115-0.108)]$.

In contrast, the path coefficient between Pilot CEO and Future_Vol [ $p$ (Pilot CEO, Future_Vol $)=0.040]$ is significant and positive at the 5\% level, indicating that pilot CEOs are associated with more volatile future firm value. The path coefficient between Future_Vol and Rating2 $[p($ Future_Vol, Rating 2$)=-2.665]$ is significantly negative at the $1 \%$ level, suggesting that when future firm value is more volatile, credit ratings get worse. The total mediated path for the variability of future firm value $[p($ Pilot CEO, Future_Vol $) \times p($ Future_Vol, Rating2 $)=-0.108]$ 
is significant and negative at the $1 \%$ level. This evidence implies that among the total effect of Pilot CEO on Rating2, about 11.9 percent is attributable to the variability of future firm value [$0.108 /(-0.688-0.115-0.108)]$. Therefore, among the different paths through which pilot CEOs affect credit ratings, the direct path of qualitative analysis of managerial risk tolerance appears to be the most important, with a magnitude much bigger than that of the two indirect paths, while the two indirect paths are similar in terms of the magnitude. ${ }^{14}$

\subsection{Cross-sectional analyses}

To further corroborate the direct path through which pilot CEOs affect credit ratings (i.e., rating agencies' assessment of management), we perform a set of cross-sectional analyses based on situations under which management plays a bigger role in influencing firm outcomes. Specifically, we conduct cross-sectional analyses based on the following variables: product market competition, industry growth, and financial constraints. Management should have the largest impact on firm outcomes when firms face intense product market competition, operate in highgrowth industry, and have serious financial constraints (e.g., Bonsall et al. 2017; Cornaggia et al. 2017). The rationale is that management decisions tend to make bigger differences when firms operate in competitive environment and in financially constrained situations. Managers could also have a larger impact on the future direction of the firm when industry growth potential is high. Accordingly, under these cases, managers' personal traits such as risk tolerance could play a more important role in various corporate outcomes, and thus matter more to credit risk evaluations by rating analysts. Drawing upon the above discussions, we predict that the relation between pilot CEOs and credit ratings is stronger when firms face intense product market competition, operate in high-growth industries, and have serious financial constraints.

\footnotetext{
${ }^{14}$ As a robustness check, we alternatively add control variables in our baseline model into equation (3B) and (3C) and then re-run the path analyses. Untabulated results are qualitatively similar to those reported in Table 7.
} 
To test the above prediction, we follow Kim et al. (2011b) and Cornaggia et al. (2017) to measure product market competition using the Herfindahl-Hirschman index (HHI) based on FamaFrench 30 industries. A high index corresponds to low product market competition. Specifically, we define an indicator variable $H i g h \_H H I$ that takes one if a firm is in a highly concentrated industry (i.e., an industry with low product market competition) and zero otherwise. We follow Bonsall et al. (2017) to identify the healthcare, medical equipment, computer, and pharmaceutical industries as high-growth industries and define an indicator variable HighGrowth that equals one if a firm operates in these industries and zero otherwise. We use the delay investment score constructed by Hoberg and Maksimovic (2015) to capture financial constraints and define High_FinCon as an indicator variable that equals one if this score is in the top quantile of the industry-years and zero otherwise. ${ }^{15}$

Next, we re-estimate equation (1) after including each of these partitioning variables one at a time and its interaction with Pilot CEO, as well as Future_TobinQ and Future_Vol. The inclusion of Future_TobinQ and Future_Vol aims to control for the indirect paths, the level and the variability of future firm value, through which pilot CEOs affect credit ratings and to allow the cross-sectional analyses to better speak to the direct path.

Table 8 presents the regression results. As shown in columns 1 and 2, the coefficient on Pilot CEO $\times$ High_HHI is positive and significant, suggesting that the negative relation between CEO risk tolerance and credit ratings is weaker when firms are in a highly concentrated industry (i.e., an industry with low product market competition). In other words, the negative association between CEO risk tolerance and credit ratings is more pronounced when product market

\footnotetext{
${ }^{15}$ Hoberg and Maksimovic (2015) uses a textual analysis of the MD\&A section of 10-K filings to derive a "delay investment score" that identifies firms at risk of delaying their investments due to issues with liquidity. They find that their measure outperforms other measures of financial constraints used in the literature regarding the ability to predict policy curtailments.
} 
competition is more intense. Columns 3 and 4 both show a negative and significant coefficient on Pilot CEO $\times$ HighGrowth, indicating that the negative association between CEO risk tolerance and credit rating is more pronounced when firms operate in a high-growth industry. Similarly, columns 5 and 6 show a negative and significant coefficient on Pilot CEO $\times$ High_FinCon, implying that the negative relation between CEO risk tolerance and credit ratings is stronger when firms face serious financial constraints. Collectively, the results of cross-sectional analyses reported in Table 8 suggest that the association between $\mathrm{CEO}$ risk tolerance and credit rating is stronger when management has a bigger impact on firm outcomes, lending further support to the direct path of rating agencies' management analysis.

\section{Conclusion}

Credit ratings agencies have long emphasized the importance of assessing managerial risk tolerance in the rating process (S\&P 2008; Ganguin and Bilardello 2005). However, prior studies have not examined the implications of managerial risk tolerance for credit ratings. To fill this void in the literature, we examine the relation between managerial risk tolerance and credit ratings. In particular, we focus on a CEO' risk tolerance since he/she has the most influence over numerous decisions of a firm and set the tone of the management team and the firm (e.g., Cheng and Lo 2006; Graham, Harvey, and Puri 2013).

Using the possession of a pilot license to capture CEO risk tolerance, we find that firms led by pilot CEOs have worse credit ratings after controlling for firm fundamentals, CEO risktaking incentives, and other CEO characteristics. We use various approaches to address the endogeneity concern, including firm fixed effects regression and difference-in-difference analysis, and continue to find a negative association between CEO risk tolerance and credit rating. To 
understand how CEO risk tolerance affects credit ratings, we explore the mechanisms underlying the relation between CEO risk tolerance and credit rating. Using path analyses, we document that risk-tolerant CEOs contribute to worse ratings by reducing the level of future firm value (indirect path), increasing the volatility of future firm value (indirect path), and adversely affecting rating agencies' assessment about the implication of management for credit risk (direct path). The crosssectional analyses further confirm the direct path by showing that the relation between CEO risk tolerance and credit rating becomes stronger when management is likely to has a more significant impact on corporate outcomes.

Overall, our study sheds light on the dark side of managerial risk tolerance by showing its adverse impact on corporate credit ratings. To the extent that intrinsic risk-taking tendencies cannot be easily mitigated through compensation contracts, boards of directors can use CEOs' innate, personal traits, i.e., managerial risk tolerance, to identify CEOs who are likely to lead to worse credit ratings.

Our study is subject to several caveats. First, piloting is one of many activities that individuals with inherent risk-taking tendencies could pursue; hence, our measure may have some noise that introduces a conservative bias into our results. Given that this bias works against finding a significant relation between pilot CEOs and credit ratings, our results give credence to the implication of managerial risk tolerance for credit ratings. Second, although we have used a variety of ways to address the endogeneity concerns as discussed earlier, we cannot completely rule out the possibility that our results are driven by some correlated unobserved (and thus omitted) variables that are not considered in our analyses. 


\section{References}

Alissa, W., S. B. Bonsall IV, K. Koharki, and M. W. Penn Jr. 2013. Firms' use of accounting discretion to influence their credit ratings. Journal of Accounting \& Economics 55(2): 12947.

Amato, J. D., and C. H. Furfine. 2004. Are credit ratings procyclical? Journal of Banking \& Finance 28(11): 2641-2677.

Argenti, P., R. Howell, and K. Beck. 2005. The strategic communication imperative. MIT Sloan Management Review 46(3): 82-89.

Ashbaugh-Skaife, H., D. W. Collins, and R. LaFond. 2006. The effects of corporate governance on firms' credit ratings. Journal of Accounting \& Economics 42 (1-2): 203-243.

Baron, R. M., and D. A. Kenny. 1986. The moderator-mediator variable distinction in social psychological research: Conceptual, strategic, and statistical considerations. Journal of Personality and Social Psychology 51(6): 1173-1182.

Beaver, W., Shakespeare, C., and Soliman, M., 2006. Differential properties in the ratings of certified versus non-certified bond-rating agencies. Journal of Accounting and Economics 42 (3): 303-334.

Bebchuk, L.A. 2009. Written testimony, hearing on compensation structures and systemic risk. Committee on Financial Services, US House of Representatives, June, 11.

Becker, G. S. 1968. Crime and punishment: An economic approach. Journal of Political Economy 76: $169-169$.

Becker, B. and T. Milbourn. 2011. How did increased competition affect credit ratings? Journal of Financial Economics 101(3): 493-514.

Bernile, G., V. Bhagwat, and P. R. RAU. 2017. What doesn't kill you will only make you more risk-loving: early-life disasters and CEO behavior. Journal of Finance 72: 167-206.

Bertrand, M., and S. Mullainathan. 2003. Enjoying the quiet life? Corporate governance and managerial preferences. Journal of Political Economy 111(5): 1043-1075.

Bertrand, M., and A. Schoar. 2003. Managing with style: the effect of managers on firm policies. The Quarterly Journal of Economics 118(4): 1169-1208.

Blume, M. E., F. Lim, and A. C. MacKinlay. 1998. The declining credit quality of US corporate debt: Myth or reality? Journal of Finance 53(4): 1389-1413.

Boardman, C. M., and R. W. McEnally. 1981. Factors affecting seasoned corporate bond prices. Journal of Financial and Quantitative Analysis 16 (2): 207-226. 
Bonsall IV, S. B., E. R. Holzman, and B. P. Miller. 2016. Managerial ability and credit risk assessment. Management Science 63(5): 1425-1449.

Bonsall IV, S. B., K. Koharki, and M. Neamtiu. 2017. When do differences in credit rating methodologies matter? Evidence from high information uncertainty borrowers. The Accounting Review 92(4): 53-79.

Cain, M., and S. McKeon. 2016. CEO personal risk-taking and corporate policies. Journal of Financial and Quantitative Analysis 51(1): 139-164.

Cameron, A. C., Gelbach, J. B., \& Miller, D. L. (2011). Robust inference with multiway clustering. Journal of Business \& Economic Statistics, 29(2), 238-249.

Campbell, J. Y., and G. B. Taksler. 2003. Equity volatility and corporate bond yields. Journal of Finance 58(6): 2321-2350.

Cantor, R., and F. Packer. 1995. The credit rating industry. Journal of Fixed Income 5(3):10-34.

Castillo-Manzano, J. I., C. Mercedes, and X. Fageda. 2015. Are traffic violators criminals? Searching for answers in the experiences of European countries. Transport Policy 38: 8694.

Chen, Y., Gul, F. A., Veeraraghavan, M., \& Zolotoy, L. (2015). Executive equity risk-taking incentives and audit pricing. The Accounting Review, 90(6), 2205-2234.

Chen, D., J. B. Kim, O. Z. Li, and S. Liang. 2018. China's closed pyramidal managerial labor market and the stock price crash risk. The Accounting Review 93(3): 105-131.

Cheng, Q., and K. Lo. 2006. Insider trading and voluntary disclosures. Journal of Accounting Research 44: 815-848.

Chiu, T.-T., Y. Guan, and J.-B. Kim (2018). "Effect of risk factor disclosures on the pricing of credit default swaps." Contemporary Accounting Research 35 (4): 2191-2224.

Coles, J., N. Daniel, and L. Naveen. 2006. Managerial incentives and risk-taking. Journal of Financial Economics 79: 431-468.

Collins, J. M., and F. L. Schmidt. 1993. Personality, integrity, and white collar crime: A construct validity study. Personnel Psychology 46: 295-311.

Core, J., \& Guay, W. (2002). Estimating the value of employee stock option portfolios and their sensitivities to price and volatility. Journal of Accounting research, 40(3), 613-630.

Cornaggia, K. J., G. V. Krishnan, and C. Wang. 2017. Managerial ability and credit ratings. Contemporary Accounting Research 34(4): 2094-2122. 
Davidson, R., A. Dey, and A. Smith. 2015. Executives' “off-the-job” behavior, corporate culture, and financial reporting risk. Journal of Financial Economics 117(1): 5-28.

Defond, M. L., C. Y. Lim, and Y. Zang. 2016. Client conservatism and auditor-client contracting. The Accounting Review 91(1): 69-98.

Duffie, D., and D. Lando. 2001. Term structures of credit spreads with incomplete accounting information. Econometrica 69 (3): 633-664.

Ederington, L.H., and J. C. Goh. 1998. Bond rating agencies and stock analysts: who knows what when? Journal of Financial and Quantitative Analysis 33(4): 569-585.

Eide, E., P. Rubin, and J. M. Shepherd. 2006. Economics of crime. Foundations and Trends in Microeconomics 2(3): 205-279.

Ehrlich, I. 1973. Participation in illegitimate activities: A theoretical and empirical investigation. Journal of Political Economy 81(3): 521-65.

Fisman, R., and E. Miguel. 2007. Corruption, norms, and legal enforcement: evidence from diplomatic parking tickets. Journal of Political Economy 115(6): 1020-1048.

Ganguin, B., and J. Bilardello. 2005. Fundamentals of corporate credit analysis. New York: McGraw-Hill.

Garoupa, N. 2003. Behavioral economic analysis of crime: A critical review. European Journal of Law and Economics 15(1): 5-15.

Gervais, S., J. B. Heaton, and T. Odean. 2011. Overconfidence, compensation contracts, and capital budgeting. Journal of Finance 66: 1735-1777.

Goel, A. M., and A. V. Thakor. 2008. Overconfidence, CEO selection, and corporate governance. Journal of Finance 63: 2737-2784.

Gormley, T. A., and D. A. Matsa. 2016. Playing it safe? Managerial preferences, risk, and agency conflicts. Journal of Financial Economics 122(3): 431-455.

Gottfredson, M. R., and T. Hirschi. 1990. A general theory of crime. Stanford University Press.

Graham, J., 2017. Global business outlook. Duke-CFO Magazine Q2, 1-2.

Graham, J. R., and C. R. Harvey. 2001. The theory and practice of corporate finance: evidence from the field. Journal of Financial Economics 60(2-3):187-243.

Graham, J. R., C. R. Harvey, and M. Puri. 2013. Managerial attitudes and corporate actions. Journal of Financial Economics 109(1), 103-121. 
Ham, C., and K. Koharki. 2016. The association between corporate general counsel and firm credit risk. Journal of Accounting and Economics 61(2-3), pp.274-293.

Hand, J. R., R. W. Holthausen, and R. W. Leftwich. 1992. The effect of bond rating agency announcements on bond and stock prices. Journal of Finance 47(2):733-752.

Harris, M. and A. Raviv. 1990. Capital structure and the informational role of debt. Journal of Finance 45(2): 321-49.

Hirshleifer, D., A. Low, and S. H. Teoh. 2012. Are overconfident CEOs better innovators? Journal of Finance 67: 1457-1498.

Hoberg, G., and V. Maksimovic, 2015. Redefining financial constraints: A text-based analysis. Review of Financial Studies 28(5): 1312-1352.

Holthausen, R.W., and R. W Leftwich. 1986. The effect of bond rating changes on common stock prices. Journal of Financial Economics 17(1):57-89.

Horrigan J. 1966. The determination of long-term credit standing with financial ratios. Journal of Accounting Research 4: 44-62.

Hrazdil, K., Novak, J., Rogo, R., Wiedman, C. I., \& Zhang, R. (2018). Measuring CEO Personality Using Machine-Learning Algorithms: A Study of CEO Risk Tolerance and Audit Fees. Available at SSRN: https://ssrn.com/abstract=3101500.

Hvide, H. K., and G. Panos. 2014. Risk tolerance and entrepreneurship. Journal of Financial Economics 111: 200-223.

Iversen, H., and T. Rundmo. 2002. Personality, risky driving and accident involvement among Norwegian drivers. Personality and Individual Differences 33(8): 1251-1263.

Junger, M., R. West, and R. Timman. 2001. Crime and risky behavior in traffic: An example of cross-situational consistency. Journal of Research in Crime and Delinquency 38: 439-459.

Kaplan, R.S., and G. Urwitz. 1979. Statistical models of bond ratings: A methodological inquiry. Journal of business 52(2): 231-261.

Kisgen, D. J. 2006. Credit ratings and capital structure. Journal of Finance 61(3):1035-1072.

Kisgen, D. J. 2007. The influence of credit ratings on corporate capital structure decisions. Journal of Applied Corporate Finance 19(3): 65-73.

Kim, J.-B., Li, Y., \& Zhang, L. (2011b). CFOs versus CEOs: Equity incentives and crashes. Journal of Financial Economics, 101(3), 713-730. 
Kim, J.-B., Z. Wang, and L. Zhang (2016) "CEO Over-Confidence and Stock Price Crash Risk." Contemporary Accounting Research 33 (4): 1720-1749.

Kim, J. B., E. X. Zhang, and K. Zhong. 2019. The bright side of unionization: The case of stock price crash risk. Available at SSRN: https://ssrn.com/abstract=3394379.

Koharki, K., M. Ringgenberg, and L. Watson. 2019. Risk can be good: The tradeoff between agency conflicts, CEO risk-taking incentives, and credit risk. Available at SSRN: https://ssrn.com/abstract=3200110.

Kraft, P. 2015. Rating agency's adjustments to GAAP financial statements and their effect on ratings and credit spreads. The Accounting Review 90(2): 641-74.

Kuang, Y. F., and B. Qin. 2013. Credit ratings and CEO risk-taking incentives. Contemporary Accounting Research 30(4): 1524-1559.

Lamy, R. E., and G. R. Thompson. 1988. Risk premia and the pricing of primary issue bonds. Journal of Banking \& Finance 12(4): 585-601.

Lee, L., 2012. Incentives to inflate reported cash from operations using classification and timing. The Accounting Review 87(1): 1-33.

Malmendier, U., and G. A. TATE. 2005. CEO overconfidence and corporate investment. Journal of Finance 60: 2661-2700.

Malmendier, U., G. A. Tate and J. Yan. 2011. Overconfidence and early-life experiences: The effect of managerial traits on corporate financial policies. Journal of Finance 66(5): 16871733.

McFall, M. C. 1992. Lincoln national aviation mortality and claim analysis. North American Actuarial Journal 33: 6-8.

Morgan, D. P. 2002. Rating banks: Risk and uncertainty in an opaque industry. American Economic Review 92 (4): 874-888.

Palmer, E. J., and C. R, Hollin. 2004. The use of the psychological inventory of criminal thinking styles with English young offenders. Legal and Criminological Psychology 9: 253-263.

Petersen, M. A. 2009. Estimating standard errors in finance panel data sets: Comparing approaches. Review of Financial Studies 22(1): 435-80.

Pevzner, M., F. Xie, and X. Xin. 2015. When firms talk, do investors listen? The role of trust in stock market reactions to corporate earnings announcements. Journal of Financial Economics 117(1): 190-223. 
Pittman, J. A., S. E. Stein, and D. F. Valentine. 2019. Audit partners' risk tolerance and the impact on audit quality. Available at SSRN: https://ssrn.com/abstract=3311682 or http://dx.doi.org/10.2139/ssrn.3311682

Walters, G. 2009. The psychological inventory of criminal thinking styles and psychopathy checklist: Screening version as incrementally valid predictors of recidivism. Law and Human Behavior 33: 497-505.

Roussanov, N., and P. Savor. 2012. Status, marriage, and managers' attitudes to risk. Working Paper, University of Pennsylvania.

Roychowdhury, S. 2006. Earnings management through real activities manipulation, Journal of Accounting and Economics 42(3): 335-370.

Securities and Exchange Commission. 2011. SEC Seeks Public Comment in Study on Assigned Credit Ratings. Release 2011-108. May 10, 2011. Washington, DC: Available at: http://www.sec.gov/news/press/2011/2011-108.htm

Standard and Poor's. 2008. Corporate ratings criteria. Available at: http://www.nafoa.org/pdf/CorprateCriteriaBook-2008.pdf

Sunder, J., S. V. Sunder, and J. Zhang. 2017. Pilot CEOs and corporate innovation. Journal of Financial Economics 123: 209-224.

Williamson, O. E. 1988. Corporate Finance and Corporate Governance. Journal of Finance 43: 567-591.

Giroud, X., and H. M. Mueller. 2010. Does corporate governance matter in competitive industries? Journal of Financial Economics 95(3): 312-331.

Zhang, X. "Do firms manage credit ratings? Evidence from rating-based contracts," Accounting Horizons, 32(4) (2018), 163-183.

Ziebard, D. A., and S. A. Reiter. 1992. Bond ratings, bond yields and financial information. Contemporary Accounting Research 9: 252-282. 


\begin{tabular}{|c|c|c|}
\hline Variable & Definition & Source \\
\hline \multicolumn{3}{|c|}{ CEO Characteristics } \\
\hline Pilot CEO & $\begin{array}{l}\text { An indicator variable that takes the value } \\
\text { of one if a CEO holds a pilot license, and } \\
\text { zero otherwise }\end{array}$ & FAA \\
\hline Age & The age of a CEO & Execucomp \\
\hline Tenure & Years of service as CEO at given firm & Execucomp \\
\hline Military & $\begin{array}{l}\text { An indicator variable that takes the value } \\
\text { of one if a CEO has military experience, } \\
\text { and } 0 \text { otherwise }\end{array}$ & BoardEx \\
\hline LogVega & $\begin{array}{l}\text { The natural log of one plus the volatility } \\
\text { sensitivity, where the volatility sensitivity } \\
\text { is defined as the dollar change in the } \\
\text { CEO's option holdings in response to } 0.01 \\
\text { unit change in stock return volatility (Core } \\
\text { and Guay 2002; Chen et al. 2015) }\end{array}$ & Execucomp \\
\hline LogDelta & $\begin{array}{l}\text { The natural log of one plus the price } \\
\text { sensitivity, where the price sensitivity is } \\
\text { defined as the dollar change in the CEO's } \\
\text { stock and option holdings with regard to a } \\
1 \text { percent change in stock price (Core and } \\
\text { Guay 2002; Chen et al. 2015) }\end{array}$ & Execucomp \\
\hline Overconfidence & $\begin{array}{l}\text { The natural } \log \text { of the } \\
\text { ratio of a given CEO's vested in-the- } \\
\text { money option value to the CEO's total } \\
\text { compensation value }\end{array}$ & Execucomp \\
\hline \multicolumn{3}{|c|}{ Firm Characteristics } \\
\hline Size & The natural logarithm of total assets. & Compustat \\
\hline Leverage & Total debt divided by total equity & Compustat \\
\hline$R O A$ & $\begin{array}{l}\text { Net income before extraordinary items } \\
\text { divided by total assets }\end{array}$ & Compustat \\
\hline Loss & $\begin{array}{l}\text { An indicator variable that takes the value of } \\
\text { one if a firm's income before extraordinary } \\
\text { items is negative in the current or prior } \\
\text { fiscal year, and zero otherwise }\end{array}$ & Compustat \\
\hline Cap_inten & Gross PPE divided by total assets & Compustat \\
\hline Int_cov & $\begin{array}{l}\text { Operating income before depreciation } \\
\text { divided by interest expense }\end{array}$ & Compustat \\
\hline Subord & $\begin{array}{l}\text { An indicator variable that takes the value of } \\
\text { one if a firm has subordinated debt, and } \\
\text { zero otherwise }\end{array}$ & Compustat \\
\hline LogVol & $\begin{array}{l}\text { Natural log of return volatility, where return } \\
\text { volatility is calculated as the standard } \\
\text { deviation of abnormal daily stock returns } \\
\text { (i.e., the daily return minus the value- } \\
\text { weighted market return) in a fiscal year }\end{array}$ & CRSP \\
\hline
\end{tabular}




\begin{tabular}{|c|c|c|}
\hline Future_Tobin $Q$ & $\begin{array}{l}\text { One-year-ahead Tobin's Q, where Tobin's } \\
\text { Q is defined as total liabilities plus market } \\
\text { value of equity divided by total assets }\end{array}$ & Compustat \\
\hline Future_Vol & One-year-ahead LogVol & CRSP \\
\hline \multicolumn{3}{|c|}{ Corporate Credit Ratings } \\
\hline Rating 1 & $\begin{array}{l}\text { The assigned numeric rating score following } \\
\text { Ashbaugh-Skaife, Collins, and LaFond } \\
\text { (2006) }\end{array}$ & Compustat \\
\hline Rating2 & $\begin{array}{l}\text { The assigned numeric rating score following } \\
\text { Becker and Milbourn (2011) }\end{array}$ & Compustat \\
\hline \multicolumn{3}{|l|}{ Other variables } \\
\hline Managerial Ability & $\begin{array}{l}\text { The managerial ability score constructed by } \\
\text { Demerjian et al. (2012) }\end{array}$ & $\begin{array}{l}\text { Demerjian et } \\
\text { al. (2012) }\end{array}$ \\
\hline Board Size & The number of directors on the board & ISS \\
\hline Board Independence & $\begin{array}{l}\text { The number of independent directors divided } \\
\text { by board size }\end{array}$ & ISS \\
\hline CEO Duality & $\begin{array}{l}\text { An indicator variable that equals one if a } \\
\text { CEO also serve as chair of the board }\end{array}$ & ISS \\
\hline Insider Voting Power & $\begin{array}{l}\text { The percentage voting power held by inside } \\
\text { directors }\end{array}$ & ISS \\
\hline
\end{tabular}


FIGURE 1

Paths between Pilot CEO and Credit Rating Variables

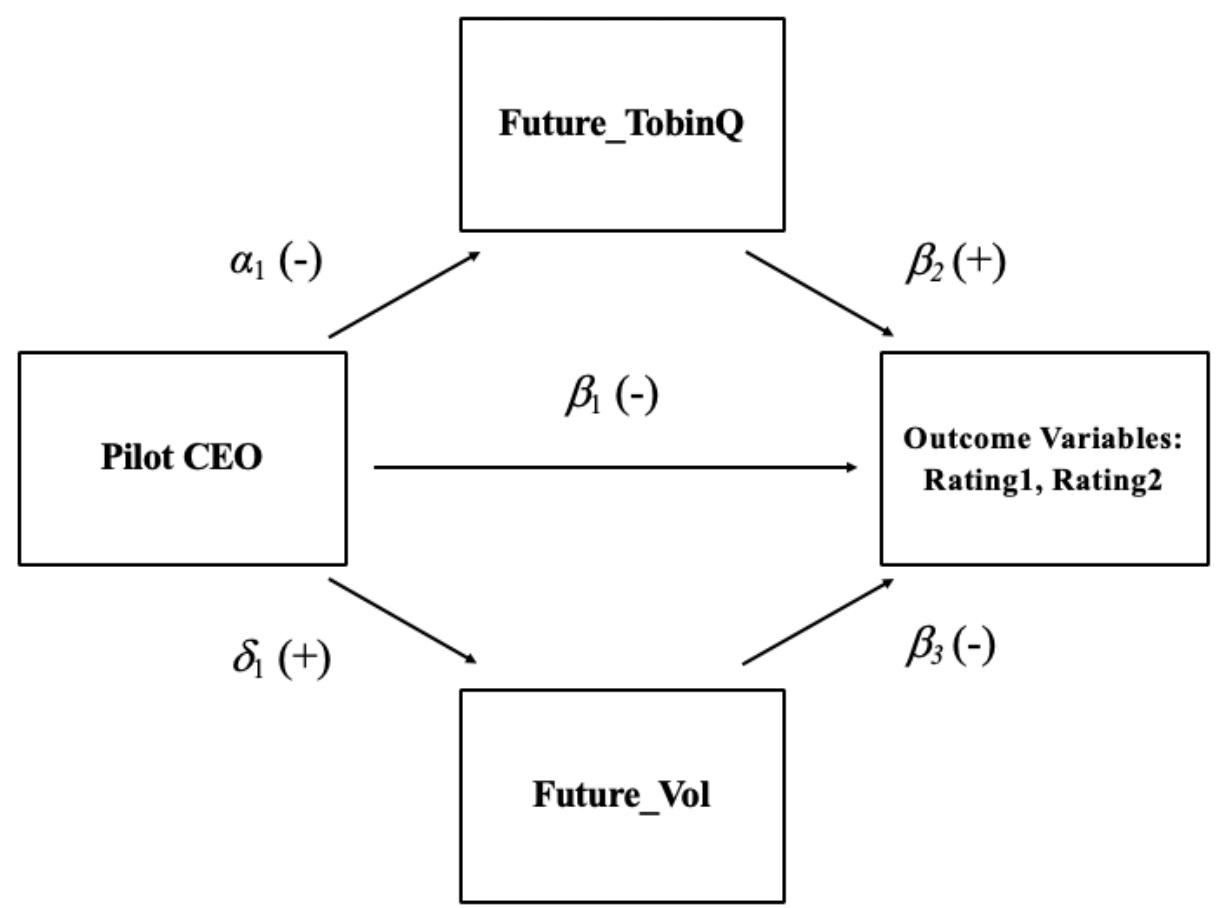

The figure depicts the direct and indirect paths through which pilot CEOs (Pilot CEO) are expected to influence the two outcome variables (Rating1 and Rating2). We expect Pilot CEO to directly affect the outcome variables through its effect on credit agencies' qualitative assessment of an issuer's managerial risk tolerance, and indirectly affect the outcome variables through its effect on the level (Future_TobinQ) and the variance of future firm value (Future_Vol). The following models are estimated:

$$
\begin{aligned}
& \begin{aligned}
\text { Rating1 }(\text { or Rating2)= } & \beta_{0}+\beta_{1} \text { Pilot CEO }+\beta_{2} \text { Future_Tobin } Q+\beta_{3} \text { Future_Vol } \\
& +\beta \mathrm{kControls}+\text { Industry FE }+ \text { Year FE }+\varepsilon
\end{aligned} \\
& \begin{aligned}
\text { Future_Tobin } Q= & \alpha_{0}+\alpha_{1} \text { Pilot } C E O+\text { Industry FE }+ \text { Year FE }+\mu \\
\text { Future_Vol }= & \delta_{0}+\delta_{1} \text { Pilot CEO }+ \text { Industry FE }+ \text { Year FE }+\Psi
\end{aligned}
\end{aligned}
$$

where controls are the control variables included in equation (1); all the variables are defined in Appendix. The path coefficient $\beta_{1}$ is the magnitude of the direct path from Pilot CEO to the rating variables. The path coefficient $\alpha_{1}\left(\delta_{1}\right)$ is the magnitude of the path coefficient from Pilot CEO to Future_TobinQ (Future_Vol). The path coefficient $\beta_{2}\left(\beta_{3}\right)$ is the magnitude of the path from Future_TobinQ (Future_Vol) to the rating variables. The path coefficient $\alpha_{1} \times \beta_{2}\left(\delta_{1} \times \beta_{3}\right)$ measures the magnitude of the indirect path from Pilot $C E O$ to the rating variables mediated through Future_TobinQ (Future_Vol). The predicted signs of the path coefficients are included in parentheses. 


\section{Table 1 Summary Statistics}

This table presents summary statistics. Panel A reports descriptive statistics of corporate credit ratings, CEO pilot status, and control variables used in the analyses. Panel B compares the mean and median of corporate credit ratings and control variables for firms led by pilot CEOs and firms led by non-pilot CEOs. The sample period is from 1992 to 2016. All variables are defined in Appendix.

Panel A: Descriptive statistics

\begin{tabular}{lcccccc}
\hline Variable & $\mathrm{N}$ & $\mathrm{P} 25$ & Mean & Median & P75 & Std Dev \\
\hline Rating1 & 13020 & 3.000 & 3.809 & 4.000 & 5.000 & 1.119 \\
Rating2 & 13020 & 16.000 & 18.413 & 19.000 & 21.000 & 3.329 \\
Pilot CEO & 13020 & 0.000 & 0.056 & 0.000 & 0.000 & 0.230 \\
Size & 13020 & 7.577 & 8.582 & 8.426 & 9.502 & 1.402 \\
Leverage & 13020 & 0.192 & 0.313 & 0.297 & 0.404 & 0.174 \\
ROA & 13020 & 0.017 & 0.039 & 0.042 & 0.074 & 0.071 \\
Loss & 13020 & 0.000 & 0.072 & 0.000 & 0.000 & 0.259 \\
Cap_inten & 13020 & 0.245 & 0.593 & 0.538 & 0.904 & 0.414 \\
Int_cov & 13020 & 4.042 & 12.744 & 7.170 & 13.407 & 19.407 \\
Subord & 13020 & 0.000 & 0.316 & 0.000 & 1.000 & 0.465 \\
Age & 13020 & 52.000 & 55.601 & 56.000 & 60.000 & 6.086 \\
Tenure & 13020 & 2.000 & 5.591 & 5.000 & 8.000 & 4.062 \\
Military & 13020 & 0.000 & 0.097 & 0.000 & 0.000 & 0.296 \\
LogVega & 13020 & 3.105 & 4.044 & 4.414 & 5.426 & 1.935 \\
LogDelta & 13020 & 4.601 & 5.513 & 5.561 & 6.479 & 1.484 \\
LogVol & 13020 & -4.377 & -4.015 & -4.045 & -3.702 & 0.484 \\
\hline
\end{tabular}


Panel B: Mean and median differences across firms led by pilot CEOs and firms led by non-pilot CEOs

\begin{tabular}{|c|c|c|c|c|c|c|c|c|c|c|}
\hline \multirow[b]{2}{*}{ Variable } & \multicolumn{4}{|c|}{ CEO Pilot $=1$} & \multicolumn{4}{|c|}{ CEO Pilot $=0$} & \multicolumn{2}{|c|}{ Test of differences } \\
\hline & $\mathrm{N}$ & Mean & Median & $\mathrm{SD}$ & $\mathrm{N}$ & Mean & Median & SD & t-test & $\begin{array}{c}\text { Wilcoxon } \\
\text { test }\end{array}$ \\
\hline Rating1 & 729 & 3.568 & 4.000 & 1.037 & 12291 & 3.824 & 4.000 & 1.122 & $-0.256 * * *$ & $0.000 * * *$ \\
\hline Rating2 & 729 & 17.735 & 18.000 & 3.029 & 12291 & 18.453 & 19.000 & 3.342 & $-0.718 * * *$ & $-1.000 * * *$ \\
\hline Size & 729 & 8.780 & 8.870 & 1.459 & 12291 & 8.570 & 8.409 & 1.398 & $0.211 * * *$ & $0.462 * * *$ \\
\hline Leverage & 729 & 0.343 & 0.327 & 0.189 & 12291 & 0.312 & 0.295 & 0.173 & $0.032 * * *$ & $0.031 * * *$ \\
\hline$R O A$ & 729 & 0.030 & 0.032 & 0.064 & 12291 & 0.040 & 0.043 & 0.071 & $-0.010 * * *$ & $-0.011 * * *$ \\
\hline Loss & 729 & 0.078 & 0.000 & 0.269 & 12291 & 0.072 & 0.000 & 0.258 & 0.006 & 0.000 \\
\hline Cap_inten & 729 & 0.648 & 0.636 & 0.417 & 12291 & 0.589 & 0.532 & 0.413 & $0.058 * * *$ & $0.104 * * *$ \\
\hline Int_cov & 729 & 10.691 & 5.490 & 17.720 & 12291 & 12.866 & 7.294 & 19.497 & $-2.175^{* * *}$ & $-1.804 * * *$ \\
\hline Subord & 729 & 0.383 & 0.000 & 0.486 & 12291 & 0.312 & 0.000 & 0.463 & $0.071 * * *$ & $0.000 * * *$ \\
\hline Age & 729 & 55.081 & 55.000 & 6.946 & 12291 & 55.631 & 56.000 & 6.030 & $-0.551 * * *$ & $-1.000 * *$ \\
\hline Tenure & 729 & 5.951 & 5.000 & 4.173 & 12291 & 5.569 & 5.000 & 4.054 & $0.381 * * *$ & $0.000 * *$ \\
\hline Military & 729 & 0.209 & 0.000 & 0.407 & 12291 & 0.090 & 0.000 & 0.286 & $0.118^{* * *}$ & $0.000^{* * *}$ \\
\hline LogVega & 729 & 4.121 & 4.516 & 1.938 & 12291 & 4.039 & 4.408 & 1.935 & 0.082 & 0.108 \\
\hline LogDelta & 729 & 5.645 & 5.621 & 1.659 & 12291 & 5.505 & 5.559 & 1.473 & $0.139 * * *$ & $0.062 *$ \\
\hline LogVol & 729 & -3.970 & -3.978 & 0.501 & 12291 & -4.017 & -4.048 & 0.482 & $0.048 * * *$ & $0.007 * * *$ \\
\hline
\end{tabular}




\section{Table 2 Correlations}

This table presents the correlation matrix. The lower (upper) triangle reports the Pearson (Spearman) correlation statistics. The sample period is from 1992 to 2016. All variables are defined in Appendix. Significance levels are based on two-tailed tests.

\begin{tabular}{|c|c|c|c|c|c|c|c|c|c|c|c|c|c|c|c|c|}
\hline & Pilot CEO & Rating1 & Rating2 & Size & Leverage & $R O A$ & Loss & Cap_inten & Int_Cov & Subord & Age & Tenure & Military & LogVega & LogDelta & LogVol \\
\hline Pilot CEO & & $-0.049 * * *$ & $-0.048 * * *$ & $0.039^{* * *}$ & $0.039 * * *$ & $-0.054 * * *$ & 0.006 & $0.035^{* * *}$ & $-0.058 * * *$ & $0.035 * * *$ & $-0.019^{* *}$ & $0.022^{* *}$ & $0.092 * * *$ & 0.011 & $0.015^{*}$ & $0.023 * * *$ \\
\hline Rating1 & $-0.053 * * *$ & & $0.968 * * *$ & $0.468 * * *$ & $-0.333 * * *$ & $0.375 * * *$ & $-0.328 * * *$ & $-0.020 * *$ & $0.492 * * *$ & $-0.130 * * *$ & $0.100 * * *$ & $-0.037 * * *$ & $0.052 * * *$ & $0.345 * * *$ & $0.307 * * *$ & $-0.500 * * *$ \\
\hline Rating2 & $-0.050 * * *$ & $0.973 * * *$ & & $0.478 * * *$ & $-0.334 * * *$ & $0.391 * * *$ & $-0.334 * * *$ & $-0.015^{*}$ & $0.504 * * *$ & $-0.134 * * *$ & $0.102 * * *$ & $-0.039 * * *$ & $0.051 * * *$ & $0.348 * * *$ & $0.314 * * *$ & $-0.516^{* * *}$ \\
\hline Size & $0.035^{* * *}$ & $0.478 * * *$ & $0.489^{* * *}$ & & $-0.121 * * *$ & 0.010 & $-0.096^{* * *}$ & $-0.090^{* * *}$ & $0.140 * * *$ & $-0.043^{* * *}$ & $0.117 * * *$ & $0.054^{* * *}$ & 0.011 & $0.434 * * *$ & $0.444 * * *$ & $-0.381 * * *$ \\
\hline Leverage & $0.042 * * *$ & $-0.346 * * *$ & $-0.348 * * *$ & $-0.116^{* * *}$ & & $-0.282 * * *$ & $0.177 * * *$ & $0.207 * * *$ & $-0.653 * * *$ & $0.224 * * *$ & $-0.043 * * *$ & -0.012 & -0.005 & $-0.157 * * *$ & $-0.170 * * *$ & $0.148 * * *$ \\
\hline$R O A$ & $-0.034 * * *$ & $0.397 * * *$ & $0.410^{* * *}$ & $0.071 * * *$ & $-0.249 * * *$ & & $-0.417 * * *$ & $-0.058 * * *$ & $0.700^{* * *}$ & $-0.264 * * *$ & $0.038^{* * *}$ & $0.036^{* * *}$ & $0.069 * * *$ & $0.227 * * *$ & $0.336^{* * *}$ & $-0.309 * * *$ \\
\hline Loss & 0.006 & $-0.346 * * *$ & $-0.355 * * *$ & $-0.101 * * *$ & $0.205^{* * *}$ & $-0.493 * * *$ & & $0.063 * * *$ & $-0.355 * * *$ & $0.058 * * *$ & $-0.054 * * *$ & $-0.044 * * *$ & $-0.037 * * *$ & $-0.115^{* * *}$ & $-0.174 * * *$ & $0.306^{* * *}$ \\
\hline Cap_inten & $0.032 * * *$ & $-0.032 * * *$ & $-0.030 * * *$ & $-0.100 * * *$ & $0.174 * * *$ & $-0.090 * * *$ & $0.076^{* * *}$ & & $-0.147 * * *$ & $0.054 * * *$ & $0.048 * * *$ & $-0.070 * * *$ & $0.017 *$ & $-0.182 * * *$ & $-0.258 * * *$ & $0.020^{* *}$ \\
\hline Int_cov & $-0.026 * * *$ & $0.284 * * *$ & $0.291 * * *$ & $0.073 * * *$ & $-0.444 * * *$ & $0.378 * * *$ & $-0.152 * * *$ & $-0.104 * * *$ & & $-0.344 * * *$ & $0.041 * * *$ & $0.055^{* * *}$ & $0.053 * * *$ & $0.288^{* * *}$ & $0.366 * * *$ & $-0.339 * * *$ \\
\hline Subord & $0.035^{* * *}$ & $-0.125 * * *$ & $-0.130 * * *$ & $-0.025 * * *$ & $0.211 * * *$ & $-0.187 * * *$ & $0.058 * * *$ & $0.063 * * *$ & $-0.189 * * *$ & & $-0.035^{* * *}$ & $-0.058 * * *$ & $-0.028 * * *$ & $-0.161 * * *$ & $-0.144 * * *$ & $0.080 * * *$ \\
\hline Age & $-0.021 * *$ & $0.096^{* * *}$ & $0.096^{* * *}$ & $0.127 * * *$ & $-0.042 * * *$ & $0.045 * * *$ & $-0.058 * * *$ & $0.040 * * *$ & 0.009 & $-0.032 * * *$ & & $0.272 * * *$ & $0.145^{* * *}$ & $0.047 * * *$ & $0.109^{* * *}$ & $-0.136^{* * *}$ \\
\hline Tenure & $0.022^{* *}$ & $-0.059 * * *$ & $-0.062 * * *$ & $0.051 * * *$ & -0.002 & $0.018^{* *}$ & $-0.033 * * *$ & $-0.062 * * *$ & $0.017^{*}$ & $-0.057 * * *$ & $0.276^{* * *}$ & & $0.040 * * *$ & $0.146^{* * *}$ & $0.300^{* * *}$ & $-0.086^{* * *}$ \\
\hline Military & $0.092 * * *$ & $0.054 * * *$ & $0.054 * * *$ & $0.020^{* *}$ & -0.010 & $0.061 * * *$ & $-0.037 * * *$ & 0.000 & $0.053 * * *$ & $-0.028 * * *$ & $0.147 * * *$ & $0.047 * * *$ & & $0.044 * * *$ & $0.076^{* * *}$ & $-0.071 * * *$ \\
\hline LogVega & 0.010 & $0.288 * * *$ & $0.291 * * *$ & $0.339 * * *$ & $-0.142 * * *$ & $0.188 * * *$ & $-0.097 * * *$ & $-0.163 * * *$ & $0.144 * * *$ & $-0.142 * * *$ & $0.017^{*}$ & $0.080 * * *$ & $0.024 * * *$ & & $0.680^{* * *}$ & $-0.204 * * *$ \\
\hline LogDelta & $0.022 * *$ & $0.295 * * *$ & $0.304 * * *$ & $0.433 * * *$ & $-0.160 * * *$ & $0.317 * * *$ & $-0.181 * * *$ & $-0.255^{* * *}$ & $0.231 * * *$ & $-0.144 * * *$ & $0.105 * * *$ & $0.289 * * *$ & $0.081 * * *$ & $0.600 * * *$ & & $-0.256 * * *$ \\
\hline Log Vol & $0.023 * * *$ & $-0.517 * * *$ & $-0.531 * * *$ & $-0.372 * * *$ & $0.190^{* * *}$ & $-0.392 * * *$ & $0.351 * * *$ & $0.027^{* * *}$ & $-0.146 * * *$ & $0.087 * * *$ & $-0.140^{* * *}$ & $-0.076^{* * *}$ & $-0.074 * * *$ & $-0.151 * * *$ & $-0.259^{* * *}$ & \\
\hline
\end{tabular}


Table 3 Pilot CEO and corporate credit ratings

This table reports the OLS regressions of credit rating variables on Pilot CEO and control variables. The sample period is from 1992 to 2016 . All variables are defined in Appendix. Each of the continuous variables is winsorized at the $1 \%$ and $99 \%$ levels to mitigate the effect of outliers. Standard errors are reported in parentheses. ***, **, and * indicate statistical significance at the 1\%, 5\%, and 10\% levels, respectively, using twotailed tests and standard errors clustered by firm.

\begin{tabular}{|c|c|c|c|c|c|c|c|c|}
\hline Variable & $\begin{array}{c}1) \\
\text { Rating1 }\end{array}$ & $\begin{array}{c}(2) \\
\text { Rating2 }\end{array}$ & $\begin{array}{c}3) \\
\text { Rating1 }\end{array}$ & $\begin{array}{c}(4) \\
\text { Rating2 }\end{array}$ & $\begin{array}{c}5) \\
\text { Rating1 }\end{array}$ & $\begin{array}{c}(6) \\
\text { Rating2 }\end{array}$ & $\begin{array}{c}\text { (7) } \\
\text { Rating1 }\end{array}$ & $\begin{array}{c}8) \\
\text { Rating2 }\end{array}$ \\
\hline Pilot CEO & $\begin{array}{c}-\mathbf{0 . 2 8 2} * * * \\
(0.100)\end{array}$ & $\begin{array}{c}-0.780 * * * \\
(0.293)\end{array}$ & $\begin{array}{c}-\mathbf{- 0 . 3 3 5} * * * \\
(0.0882)\end{array}$ & $\begin{array}{c}-0.941 * * * \\
(0.255)\end{array}$ & $\begin{array}{c}-0.252 * * * \\
(0.056)\end{array}$ & $\begin{array}{c}-0.688 * * * \\
(0.161)\end{array}$ & $\begin{array}{c}-\mathbf{0 . 2 5 1} * * * \\
(0.056)\end{array}$ & $\begin{array}{c}-0.684 * * * \\
(0.162)\end{array}$ \\
\hline Size & & & & & $\begin{array}{c}0.303 * * * \\
(0.017)\end{array}$ & $\begin{array}{c}0.918 * * * \\
(0.051)\end{array}$ & $\begin{array}{c}0.304 * * * \\
(0.017)\end{array}$ & $\begin{array}{c}0.922 * * * \\
(0.051)\end{array}$ \\
\hline Leverage & & & & & $\begin{array}{c}-0.004 * \\
(0.002)\end{array}$ & $\begin{array}{c}-0.011 \\
(0.007)\end{array}$ & $\begin{array}{l}-0.004^{*} \\
(0.002)\end{array}$ & $\begin{array}{c}-0.011 \\
(0.007)\end{array}$ \\
\hline$R O A$ & & & & & $\begin{array}{c}1.921 * * * \\
(0.214)\end{array}$ & $\begin{array}{c}5.952 * * * \\
(0.618)\end{array}$ & $\begin{array}{c}1.946^{* * *} * \\
(0.213)\end{array}$ & $\begin{array}{c}6.025^{* * * *} \\
(0.618)\end{array}$ \\
\hline Loss & & & & & $\begin{array}{l}-0.040 \\
(0.034)\end{array}$ & $\begin{array}{l}-0.137 \\
(0.095)\end{array}$ & $\begin{array}{l}-0.037 \\
(0.033)\end{array}$ & $\begin{array}{l}-0.128 \\
(0.095)\end{array}$ \\
\hline Cap_inten & & & & & $\begin{array}{c}0.097 * * \\
(0.047)\end{array}$ & $\begin{array}{c}0.341 * * \\
(0.141)\end{array}$ & $\begin{array}{c}0.094 * * \\
(0.047)\end{array}$ & $\begin{array}{c}0.333^{* *} \\
(0.141)\end{array}$ \\
\hline Int_cov & & & & & $\begin{array}{c}0.009 * * * \\
(0.001)\end{array}$ & $\begin{array}{c}0.027 * * * \\
(0.003)\end{array}$ & $\begin{array}{c}0.009 * * * \\
(0.001)\end{array}$ & $\begin{array}{c}0.027 * * * \\
(0.003)\end{array}$ \\
\hline Subord & & & & & $\begin{array}{c}-0.282 * * * \\
(0.037)\end{array}$ & $\begin{array}{c}-0.872 * * * \\
(0.112)\end{array}$ & $\begin{array}{c}-0.282 * * * \\
(0.037)\end{array}$ & $\begin{array}{c}-0.872 * * * \\
(0.111)\end{array}$ \\
\hline LogVol & & & & & $\begin{array}{c}-1.095 * * * \\
(0.039)\end{array}$ & $\begin{array}{c}-3.369 * * * \\
(0.115)\end{array}$ & $\begin{array}{c}-1.094 * * * \\
(0.039)\end{array}$ & $\begin{array}{c}-3.368 * * * \\
(0.115)\end{array}$ \\
\hline LogVega & & & $\begin{array}{c}0.112 * * * \\
(0.0140)\end{array}$ & $\begin{array}{c}0.328 * * * \\
(0.0422)\end{array}$ & $\begin{array}{c}0.023 * * * \\
(0.008)\end{array}$ & $\begin{array}{c}0.057 * * \\
(0.024)\end{array}$ & $\begin{array}{c}0.024 * * * \\
(0.008)\end{array}$ & $\begin{array}{c}0.059 * * \\
(0.024)\end{array}$ \\
\hline LogDelta & & & $\begin{array}{c}0.204 * * * \\
(0.0198)\end{array}$ & $\begin{array}{c}0.628 * * * \\
(0.0600)\end{array}$ & $\begin{array}{c}-0.026^{* *} \\
(0.012)\end{array}$ & $\begin{array}{c}-0.075^{* *} \\
(0.035)\end{array}$ & $\begin{array}{c}-0.031 * * \\
(0.012)\end{array}$ & $\begin{array}{c}-0.089 * * \\
(0.037)\end{array}$ \\
\hline
\end{tabular}


$0.002 \quad 0.005$

(0.002) (0.006)

$0.004 \quad 0.010$

(0.003) (0.009)

$-0.013 \quad-0.053$

Military

\begin{tabular}{|c|c|c|c|c|c|c|c|c|}
\hline Industry FE & YES & YES & YES & YES & YES & YES & YES & YES \\
\hline Year FE & YES & YES & YES & YES & YES & YES & YES & YES \\
\hline $\operatorname{Adj~R}{ }^{2}$ & 0.134 & 0.142 & 0.275 & 0.288 & 0.648 & 0.683 & 0.649 & 0.683 \\
\hline \# of Obs & 13,020 & 13,020 & 13,020 & 13,020 & 13,020 & 13,020 & 13,020 & 13,020 \\
\hline
\end{tabular}


Table 4 Robustness Check

This table presents the regression results of robustness checks for the relation between Pilot CEOs and corporate credit ratings. Columns 1-2 report the results using ordered logit regressions. Columns 3-4 report the results after excluding the aviation industry (SIC 3720-3730, SIC 4500-4600). The sample period for the first four columns is from 1992 to 2016. Columns 5-6 report the results using the sample of CEOs from Cain and McKeon (2016). All variables are defined in Appendix. Each of the continuous variables is winsorized at the $1 \%$ and $99 \%$ levels to mitigate the effect of outliers. Standard errors are reported in parentheses. ***, **, and * indicate statistical significance at the 1\%, 5\%, and 10\% levels, respectively, using two-tailed tests and standard errors clustered by firm.

\begin{tabular}{|c|c|c|c|c|c|c|}
\hline \multirow[b]{2}{*}{ VARIABLES } & \multicolumn{2}{|c|}{ Ordered Logit } & \multicolumn{2}{|c|}{ Excluding Aviation Industry } & \multicolumn{2}{|c|}{ Cain and McKeon (2016) } \\
\hline & $\begin{array}{c}(1) \\
\text { Rating } 1 \\
\end{array}$ & $\begin{array}{c}(2) \\
\text { Rating2 }\end{array}$ & $\begin{array}{c}(3) \\
\text { Rating1 } \\
\end{array}$ & $\begin{array}{c}(4) \\
\text { Rating2 } \\
\end{array}$ & $\begin{array}{c}(5) \\
\text { Rating1 }\end{array}$ & $\begin{array}{c}(6) \\
\text { Rating2 }\end{array}$ \\
\hline Pilot CEO & $\begin{array}{c}-0.754 * * * \\
(0.171)\end{array}$ & $\begin{array}{c}-\mathbf{- 0 . 6 5 0} * * * \\
(0.159)\end{array}$ & $\begin{array}{c}-0.230 * * * \\
(0.057)\end{array}$ & $\begin{array}{c}-\mathbf{0 . 6 1 4} * * * \\
(0.165)\end{array}$ & $\begin{array}{c}-\mathbf{0 . 2 0 4} * * * * \\
(\mathbf{0 . 0 7 8 )}\end{array}$ & $\begin{array}{c}-0.641 * * * \\
(0.219)\end{array}$ \\
\hline Size & $\begin{array}{c}0.913 * * * \\
(0.054)\end{array}$ & $\begin{array}{c}0.874 * * * \\
(0.050)\end{array}$ & $\begin{array}{c}0.307 * * * \\
(0.017)\end{array}$ & $\begin{array}{c}0.932 * * * \\
(0.052)\end{array}$ & $\begin{array}{c}0.294 * * * \\
(0.021)\end{array}$ & $\begin{array}{c}0.903 * * * \\
(0.063)\end{array}$ \\
\hline Leverage & $\begin{array}{c}-0.014 * * \\
(0.006)\end{array}$ & $\begin{array}{c}-0.014 * * \\
(0.006)\end{array}$ & $\begin{array}{c}-0.004 * \\
(0.002)\end{array}$ & $\begin{array}{l}-0.011 \\
(0.007)\end{array}$ & $\begin{array}{c}-0.003 \\
(0.003)\end{array}$ & $\begin{array}{l}-0.010 \\
(0.009)\end{array}$ \\
\hline$R O A$ & $\begin{array}{c}7.226 * * * \\
(0.754)\end{array}$ & $\begin{array}{c}7.035 * * * \\
(0.687)\end{array}$ & $\begin{array}{c}1.965 * * * \\
(0.216)\end{array}$ & $\begin{array}{c}6.093 * * * \\
(0.625)\end{array}$ & $\begin{array}{c}2.234 * * * \\
(0.270)\end{array}$ & $\begin{array}{c}6.993 * * * \\
(0.801)\end{array}$ \\
\hline Loss & $\begin{array}{l}-0.093 \\
(0.103)\end{array}$ & $\begin{array}{l}-0.140 \\
(0.094)\end{array}$ & $\begin{array}{c}-0.036 \\
(0.034)\end{array}$ & $\begin{array}{c}-0.121 \\
(0.096)\end{array}$ & $\begin{array}{l}-0.024 \\
(0.043)\end{array}$ & $\begin{array}{c}-0.086 \\
(0.122)\end{array}$ \\
\hline Cap_inten & $\begin{array}{l}0.275^{*} \\
(0.144)\end{array}$ & $\begin{array}{c}0.296 * * \\
(0.137)\end{array}$ & $\begin{array}{l}0.089^{*} \\
(0.048)\end{array}$ & $\begin{array}{c}0.320^{* *} \\
(0.143)\end{array}$ & $\begin{array}{c}0.098 \\
(0.059)\end{array}$ & $\begin{array}{c}0.331^{*} \\
(0.180)\end{array}$ \\
\hline Int_cov & $\begin{array}{c}0.026 * * * \\
(0.003)\end{array}$ & $\begin{array}{c}0.026 * * * \\
(0.003)\end{array}$ & $\begin{array}{c}0.009 * * * \\
(0.001)\end{array}$ & $\begin{array}{c}0.027 * * * \\
(0.003)\end{array}$ & $\begin{array}{c}0.009 * * * \\
(0.001)\end{array}$ & $\begin{array}{c}0.027 * * * \\
(0.004)\end{array}$ \\
\hline Subord & $\begin{array}{c}-0.902 * * * \\
(0.110)\end{array}$ & $\begin{array}{c}-0.890 * * * \\
(0.101)\end{array}$ & $\begin{array}{c}-0.281 * * * \\
(0.037)\end{array}$ & $\begin{array}{c}-0.870 * * * \\
(0.114)\end{array}$ & $\begin{array}{c}-0.292 * * * \\
(0.043)\end{array}$ & $\begin{array}{c}-0.891 * * * \\
(0.129)\end{array}$ \\
\hline LogVol & $\begin{array}{c}-3.374 * * * \\
(0.113)\end{array}$ & $\begin{array}{c}-3.361 * * * \\
(0.103)\end{array}$ & $\begin{array}{c}-1.082 * * * \\
(0.039)\end{array}$ & $\begin{array}{c}-3.324 * * * \\
(0.115)\end{array}$ & $\begin{array}{c}-1.161 * * * \\
(0.047)\end{array}$ & $\begin{array}{c}-3.560 * * * \\
(0.140)\end{array}$ \\
\hline $\operatorname{LogVega}$ & $0.076 * * *$ & $0.059 * *$ & $0.022 * * *$ & $0.053^{* *}$ & 0.017 & 0.040 \\
\hline
\end{tabular}




\begin{tabular}{|c|c|c|c|c|c|c|}
\hline & $(0.025)$ & $(0.023)$ & $(0.008)$ & $(0.024)$ & $(0.011)$ & $(0.032)$ \\
\hline \multirow{2}{*}{ LogDelta } & $-0.079 * *$ & $-0.070 * *$ & $-0.028 * *$ & $-0.081 * *$ & $-0.025 *$ & $-0.081^{*}$ \\
\hline & $(0.038)$ & $(0.036)$ & $(0.013)$ & $(0.038)$ & $(0.015)$ & $(0.044)$ \\
\hline \multirow[t]{2}{*}{ Age } & 0.005 & 0.006 & 0.002 & 0.005 & 0.001 & 0.003 \\
\hline & $(0.006)$ & $(0.006)$ & $(0.002)$ & $(0.006)$ & $(0.003)$ & $(0.008)$ \\
\hline \multirow[t]{2}{*}{ Tenure } & 0.008 & 0.007 & 0.003 & 0.009 & 0.008 & $0.026^{*}$ \\
\hline & $(0.010)$ & $(0.009)$ & $(0.003)$ & $(0.010)$ & $(0.005)$ & $(0.015)$ \\
\hline \multirow[t]{2}{*}{ Military } & -0.028 & -0.044 & -0.016 & -0.069 & -0.036 & -0.105 \\
\hline & $(0.122)$ & $(0.115)$ & $(0.042)$ & $(0.123)$ & $(0.052)$ & $(0.158)$ \\
\hline Industry FE & YES & YES & YES & YES & YES & YES \\
\hline Year FE & YES & YES & YES & YES & YES & YES \\
\hline Pseudo R-squared & 0.351 & 0.230 & & & & \\
\hline Adjusted R-squared & & & 0.647 & 0.681 & 0.643 & 0.678 \\
\hline Observations & 13,020 & 13,020 & 12.714 & 12.714 & 8.747 & 8.747 \\
\hline
\end{tabular}




\section{Table 5 Alternative explanations}

This table presents the regression results of the analyses used to address the alternative explanations for the observed relation between pilot CEOs and corporate credit ratings. Columns 1-2 report the results after excluding the $20 \%$ of youngest CEOs. Columns 3-4, 5-6, 7-8 report the results after controlling for CEO overconfidence, managerial ability, and corporate governance, respectively. The sample period is from 1992 to 2016 with the exception that the sample period after controlling for corporate governance is from 1996 to 2016. All variables are defined in Appendix. Each of the continuous variables is winsorized at the $1 \%$ and $99 \%$ levels to mitigate the effect of outliers. Standard errors are reported in parentheses. $* * * * *$, and $*$ indicate statistical significance at the $1 \%, 5 \%$, and $10 \%$ levels, respectively, using two-tailed tests and standard errors clustered by firm.

\begin{tabular}{|c|c|c|c|c|c|c|c|c|}
\hline \multirow[b]{3}{*}{ Variable } & \multicolumn{2}{|c|}{$\begin{array}{l}\text { Excluding } 20 \% \text { of } \\
\text { Youngest CEOs }\end{array}$} & \multicolumn{2}{|c|}{$\begin{array}{l}\text { Controlling for CEO } \\
\text { Overconfidence }\end{array}$} & \multicolumn{2}{|c|}{$\begin{array}{l}\text { Controlling for Managerial } \\
\text { Ability }\end{array}$} & \multicolumn{2}{|c|}{$\begin{array}{c}\text { Controlling for Governance } \\
\text { Attributes }\end{array}$} \\
\hline & (1) & (2) & (3) & (4) & $(5)$ & (6) & (7) & (8) \\
\hline & Rating 1 & Rating2 & Rating 1 & Rating2 & Rating 1 & Rating2 & Rating 1 & Rating2 \\
\hline Pilot CEO & $\begin{array}{c}-0.257 * * * \\
(0.063)\end{array}$ & $\begin{array}{c}-0.688 * * * \\
(0.179)\end{array}$ & $\begin{array}{c}-0.251 * * * \\
(0.056)\end{array}$ & $\begin{array}{c}-0.684 * * * \\
(0.161)\end{array}$ & $\begin{array}{c}-0.316 * * * \\
(0.0607)\end{array}$ & $\begin{array}{c}-0.852 * * * \\
(0.174)\end{array}$ & $\begin{array}{c}-0.275 * * * \\
(0.070)\end{array}$ & $\begin{array}{c}-0.763 * * * \\
(0.199)\end{array}$ \\
\hline Size & $\begin{array}{c}0.296 * * * \\
(0.018)\end{array}$ & $\begin{array}{l}0.902 * * * \\
(0.053)\end{array}$ & $\begin{array}{l}0.300 * * * \\
(0.017)\end{array}$ & $\begin{array}{l}0.911 * * * \\
(0.051)\end{array}$ & $\begin{array}{l}0.303 * * * \\
(0.0179)\end{array}$ & $\begin{array}{l}0.926 * * * \\
(0.0537)\end{array}$ & $\begin{array}{l}0.267 * * * \\
(0.021)\end{array}$ & $\begin{array}{l}0.843 * * * \\
(0.062)\end{array}$ \\
\hline Leverage & $\begin{array}{l}-0.003 \\
(0.002)\end{array}$ & $\begin{array}{l}-0.007 \\
(0.007)\end{array}$ & $\begin{array}{l}-0.004 * \\
(0.002)\end{array}$ & $\begin{array}{l}-0.011 \\
(0.007)\end{array}$ & $\begin{array}{c}-0.00528 * * * \\
(0.00173)\end{array}$ & $\begin{array}{c}-0.0149 * * * \\
(0.00514)\end{array}$ & $\begin{array}{c}0.000 \\
(0.004)\end{array}$ & $\begin{array}{l}-0.002 \\
(0.011)\end{array}$ \\
\hline$R O A$ & $\begin{array}{l}2.077 * * * \\
(0.252)\end{array}$ & $\begin{array}{l}6.373 * * * \\
(0.734)\end{array}$ & $\begin{array}{c}1.972 * * * \\
(0.214)\end{array}$ & $\begin{array}{c}6.091 * * * \\
(0.620)\end{array}$ & $\begin{array}{c}1.611 * * * \\
(0.214)\end{array}$ & $\begin{array}{c}5.112 * * * \\
(0.627)\end{array}$ & $\begin{array}{c}2.260 * * * \\
(0.282)\end{array}$ & $\begin{array}{c}6.684 * * * \\
(0.854)\end{array}$ \\
\hline Loss & $\begin{array}{l}-0.006 \\
(0.038)\end{array}$ & $\begin{array}{l}-0.048 \\
(0.110)\end{array}$ & $\begin{array}{l}-0.038 \\
(0.033)\end{array}$ & $\begin{array}{l}-0.132 \\
(0.094)\end{array}$ & $\begin{array}{l}-0.0141 \\
(0.0339)\end{array}$ & $\begin{array}{l}-0.0654 \\
(0.0955)\end{array}$ & $\begin{array}{c}0.063 \\
(0.045)\end{array}$ & $\begin{array}{c}0.151 \\
(0.127)\end{array}$ \\
\hline Cap_inten & $\begin{array}{c}0.119 * * \\
(0.051)\end{array}$ & $\begin{array}{c}0.413 * * * \\
(0.153)\end{array}$ & $\begin{array}{l}0.093 * \\
(0.047)\end{array}$ & $\begin{array}{l}0.329 * * \\
(0.141)\end{array}$ & $\begin{array}{l}0.119 * * \\
(0.0492)\end{array}$ & $\begin{array}{c}0.429 * * * \\
(0.146)\end{array}$ & $\begin{array}{l}0.122 * * \\
(0.062)\end{array}$ & $\begin{array}{c}0.469 * * \\
(0.184)\end{array}$ \\
\hline Int_cov & $\begin{array}{c}0.010 * * * \\
(0.001)\end{array}$ & $\begin{array}{c}0.030 * * * \\
(0.003)\end{array}$ & $\begin{array}{c}0.009 * * * \\
(0.001)\end{array}$ & $\begin{array}{c}0.027 * * * \\
(0.003)\end{array}$ & $\begin{array}{c}0.00854 * * * \\
(0.00101)\end{array}$ & $\begin{array}{c}0.0252 * * * \\
(0.00300)\end{array}$ & $\begin{array}{c}0.009 * * * \\
(0.001)\end{array}$ & $\begin{array}{c}0.025 * * * \\
(0.004)\end{array}$ \\
\hline Subord & $\begin{array}{c}-0.275^{* * *} * \\
(0.041)\end{array}$ & $\begin{array}{c}-0.850 * * * \\
(0.125)\end{array}$ & $\begin{array}{c}-0.281 * * * \\
(0.036)\end{array}$ & $\begin{array}{c}-0.869 * * * \\
(0.111)\end{array}$ & $\begin{array}{c}-0.297 * * * \\
(0.0345)\end{array}$ & $\begin{array}{c}-0.914 * * * \\
(0.103)\end{array}$ & $\begin{array}{c}-0.287 * * * \\
(0.042)\end{array}$ & $\begin{array}{c}-0.894 * * * \\
(0.124)\end{array}$ \\
\hline LogVol & $-1.091 * * *$ & $-3.376 * * *$ & $-1.095 * * *$ & $-3.371 * * *$ & $-1.091 * * *$ & $-3.369 * * *$ & $-1.043 * * *$ & $-3.232 * * *$ \\
\hline
\end{tabular}




\begin{tabular}{|c|c|c|c|c|c|c|c|c|}
\hline & $(0.043)$ & $(0.127)$ & $(0.039)$ & $(0.115)$ & $-0.316^{* * *}$ & $-0.852 * * *$ & $-0.275^{* * *}$ & $-0.763 * * *$ \\
\hline \multirow[t]{2}{*}{ LogVega } & $0.019 * *$ & $0.048^{*}$ & $0.026 * * *$ & $0.065^{* * *}$ & $0.0340 * * *$ & $0.0900 * * *$ & 0.009 & 0.017 \\
\hline & $(0.009)$ & $(0.025)$ & $(0.008)$ & $(0.024)$ & $(0.00886)$ & $(0.0257)$ & $(0.011)$ & $(0.032)$ \\
\hline \multirow[t]{2}{*}{ LogDelta } & -0.012 & -0.043 & -0.020 & -0.062 & $-0.0259 *$ & $-0.0791 * *$ & -0.007 & -0.035 \\
\hline & $(0.014)$ & $(0.040)$ & $(0.013)$ & $(0.039)$ & $(0.0136)$ & $(0.0397)$ & $(0.016)$ & $(0.046)$ \\
\hline \multirow[t]{2}{*}{ Age } & -0.003 & -0.008 & 0.002 & 0.005 & 0.00171 & 0.00338 & 0.000 & 0.002 \\
\hline & $(0.003)$ & $(0.008)$ & $(0.002)$ & $(0.006)$ & $(0.00232)$ & $(0.00669)$ & $(0.003)$ & $(0.008)$ \\
\hline \multirow[t]{2}{*}{ Tenure } & 0.004 & 0.012 & 0.004 & 0.011 & 0.00375 & 0.0118 & -0.001 & 0.001 \\
\hline & $(0.003)$ & $(0.010)$ & $(0.003)$ & $(0.009)$ & $(0.00342)$ & $(0.0103)$ & $(0.005)$ & $(0.014)$ \\
\hline \multirow[t]{2}{*}{ Military } & 0.000 & -0.036 & -0.014 & -0.056 & 0.0121 & 0.00850 & -0.048 & -0.156 \\
\hline & $(0.044)$ & $(0.131)$ & $(0.041)$ & $(0.123)$ & $(0.0457)$ & $(0.137)$ & $(0.053)$ & $(0.160)$ \\
\hline \multirow[t]{2}{*}{ CEO Overconfidence } & & & $-0.045^{* *}$ & $-0.118 * *$ & & & & \\
\hline & & & $(0.018)$ & $(0.050)$ & & & & \\
\hline \multirow[t]{2}{*}{ Managerial Ability } & & & & & $0.516 * * *$ & $1.474 * * *$ & & \\
\hline & & & & & $(0.103)$ & $(0.302)$ & & \\
\hline \multirow[t]{2}{*}{ Duality } & & & & & & & 0.010 & 0.034 \\
\hline & & & & & & & $(0.034)$ & $(0.099)$ \\
\hline \multirow{2}{*}{ Insider Voting Power } & & & & & & & 0.171 & 0.437 \\
\hline & & & & & & & $(0.120)$ & $(0.327)$ \\
\hline \multirow[t]{2}{*}{ Board Independence } & & & & & & & $0.275^{* *}$ & $0.750 * *$ \\
\hline & & & & & & & $(0.125)$ & $(0.358)$ \\
\hline \multirow{2}{*}{ Board Size } & & & & & & & $0.048 * * *$ & $0.128 * * *$ \\
\hline & & & & & & & $(0.008)$ & $(0.024)$ \\
\hline Industry FE & YES & YES & YES & YES & YES & YES & YES & YES \\
\hline Year FE & YES & YES & YES & YES & YES & YES & YES & YES \\
\hline Adjusted R-squared & 0.653 & 0.685 & 0.649 & 0.684 & 0.691 & 0.726 & 0.652 & 0.684 \\
\hline Observations & 10,090 & 10,090 & 13,020 & 13,020 & 10,406 & 10,406 & 5,453 & 5,453 \\
\hline
\end{tabular}




\section{Table 6 Addressing Endogeneity Concern}

This table presents the results of several tests used to address the endogeneity concern. Panel A presents the results of firm fixed effects regressions, Panel B presents the results of the trend analyses, while Panel $\mathrm{C}$ presents the results of the difference-in-difference analyses using a propensity-score matched sample. The sample period for Panel A and B is the whole period from 1992 to 2016; the sample period for Panel C is the 2 years before and after CEO turnover (i.e., from pilot to non-pilot CEO and vice versa) during the period 1992 to 2016. All the variables are defined in Appendix. Each of the continuous variables is winsorized at the $1 \%$ and $99 \%$ levels to mitigate the effect of outliers. Standard errors are reported in parentheses. $* * *, * *$, and $*$ indicate statistical significance at the $1 \%, 5 \%$, and $10 \%$ levels, respectively, using two-tailed tests and standard errors clustered by firm.

\section{Panel A: Firm Fixed Effects Regressions}

\begin{tabular}{|c|c|c|}
\hline Variable & $\begin{array}{c}(1) \\
\text { Rating1 }\end{array}$ & $\begin{array}{r}(2) \\
\text { Rating2 }\end{array}$ \\
\hline Pilot CEO & $\begin{array}{c}-\mathbf{0 . 1 8 9} * * * \\
(\mathbf{0 . 0 5 9})\end{array}$ & $\begin{array}{c}-0.511 * * * \\
(0.154)\end{array}$ \\
\hline Size & $\begin{array}{c}0.343 * * * \\
(0.031)\end{array}$ & $\begin{array}{c}1.079 * * * \\
(0.093)\end{array}$ \\
\hline Leverage & $\begin{array}{l}-0.002 \\
(0.002)\end{array}$ & $\begin{array}{l}-0.004 \\
(0.004)\end{array}$ \\
\hline$R O A$ & $\begin{array}{c}1.033 * * * \\
(0.157)\end{array}$ & $\begin{array}{c}3.334 * * * \\
(0.430)\end{array}$ \\
\hline Loss & $\begin{array}{l}-0.016 \\
(0.023)\end{array}$ & $\begin{array}{l}-0.055 \\
(0.061)\end{array}$ \\
\hline Cap_inten & $\begin{array}{c}0.426^{* * * *} \\
(0.086)\end{array}$ & $\begin{array}{c}1.312 * * * \\
(0.249)\end{array}$ \\
\hline Int_cov & $\begin{array}{c}0.004 * * * \\
(0.001)\end{array}$ & $\begin{array}{c}0.013 * * * \\
(0.002)\end{array}$ \\
\hline Subord & $\begin{array}{c}-0.121 * * * \\
(0.034)\end{array}$ & $\begin{array}{c}-0.388 * * * \\
(0.095)\end{array}$ \\
\hline Log Vol & $\begin{array}{c}-0.534 * * * \\
(0.034)\end{array}$ & $\begin{array}{c}-1.639 * * * \\
(0.097)\end{array}$ \\
\hline LogVega & $\begin{array}{c}0.002 \\
(0.008)\end{array}$ & $\begin{array}{l}-0.001 \\
(0.023)\end{array}$ \\
\hline LogDelta & $\begin{array}{c}0.042 * * * \\
(0.012)\end{array}$ & $\begin{array}{c}0.133 * * * \\
(0.031)\end{array}$ \\
\hline Age & $\begin{array}{c}-0.006 * * \\
(0.002)\end{array}$ & $\begin{array}{c}-0.015 * * \\
(0.007)\end{array}$ \\
\hline Tenure & $\begin{array}{c}0.001 \\
(0.003)\end{array}$ & $\begin{array}{c}0.004 \\
(0.009)\end{array}$ \\
\hline Military & $\begin{array}{c}0.008 \\
(0.048)\end{array}$ & $\begin{array}{l}-0.086 \\
(0.133)\end{array}$ \\
\hline $\begin{array}{l}\text { Firm FE } \\
\text { Year FE } \\
\text { Adj-R-squared } \\
\text { Observations }\end{array}$ & $\begin{array}{c}\text { YES } \\
\text { YES } \\
0.856 \\
13020\end{array}$ & $\begin{array}{c}\text { YES } \\
\text { YES } \\
0.890 \\
13020\end{array}$ \\
\hline
\end{tabular}


Panel B: Difference-difference analyses

\begin{tabular}{|c|c|c|}
\hline VARIABLES & $\begin{array}{c}(1) \\
\text { Rating1 }\end{array}$ & $\begin{array}{c}(2) \\
\text { Rating2 } \\
\end{array}$ \\
\hline Post $\times$ Turnover & $\begin{array}{c}-\mathbf{0 . 1 2 8} * * \\
(0.0613)\end{array}$ & $\begin{array}{c}-0.310 * \\
(0.172)\end{array}$ \\
\hline Post & $\begin{array}{l}-0.0601 \\
(0.0673)\end{array}$ & $\begin{array}{c}-0.409 * \\
(0.233)\end{array}$ \\
\hline Size & $\begin{array}{c}0.342 * * \\
(0.142)\end{array}$ & $\begin{array}{c}1.045^{* * *} * \\
(0.344)\end{array}$ \\
\hline Leverage & $\begin{array}{l}-0.00545 \\
(0.00431)\end{array}$ & $\begin{array}{l}-0.0114 \\
(0.0108)\end{array}$ \\
\hline$R O A$ & $\begin{array}{l}1.192 * \\
(0.604)\end{array}$ & $\begin{array}{c}4.218 * * * \\
(1.252)\end{array}$ \\
\hline Loss & $\begin{array}{r}-0.0104 \\
(0.101)\end{array}$ & $\begin{array}{c}0.0835 \\
(0.205)\end{array}$ \\
\hline Cap_inten & $\begin{array}{l}0.0245 \\
(0.331)\end{array}$ & $\begin{array}{c}0.0811 \\
(0.782)\end{array}$ \\
\hline Int_cov & $\begin{array}{c}0.00227 \\
(0.00178)\end{array}$ & $\begin{array}{c}0.00647 \\
(0.00422)\end{array}$ \\
\hline Subord & $\begin{array}{l}0.0181 \\
(0.122)\end{array}$ & $\begin{array}{c}-0.0463 \\
(0.288)\end{array}$ \\
\hline LogVol & $\begin{array}{c}-0.226^{*} \\
(0.133)\end{array}$ & $\begin{array}{c}-0.773 * * \\
(0.345)\end{array}$ \\
\hline $\operatorname{LogVega}$ & $\begin{array}{c}0.0255 \\
(0.0316)\end{array}$ & $\begin{array}{c}0.0598 \\
(0.0846)\end{array}$ \\
\hline LogDelta & $\begin{array}{l}0.0675^{*} \\
(0.0355)\end{array}$ & $\begin{array}{c}0.263 * * * \\
(0.0997)\end{array}$ \\
\hline Age & $\begin{array}{c}-0.00646 \\
(0.00800)\end{array}$ & $\begin{array}{l}-0.0296 \\
(0.0183)\end{array}$ \\
\hline Tenure & $\begin{array}{c}-0.00592 \\
(0.00923)\end{array}$ & $\begin{array}{l}0.00228 \\
(0.0260)\end{array}$ \\
\hline Military & $\begin{array}{l}-0.0354 \\
(0.0971)\end{array}$ & $\begin{array}{l}-0.112 \\
(0.373)\end{array}$ \\
\hline Observations & 498 & 498 \\
\hline R-squared & 0.936 & 0.961 \\
\hline Firm FE & YES & YES \\
\hline Year FE & YES & YES \\
\hline Adjusted R-squared & 0.901 & 0.939 \\
\hline
\end{tabular}


Panel C: Inclusion of lead and lag indicators for pilot CEOs

\begin{tabular}{|c|c|c|}
\hline & (1) & (2) \\
\hline VARIABLES & Rating 1 & Rating2 \\
\hline Before ${ }^{-2}$ & $\begin{array}{c}-0.018 \\
(0.058)\end{array}$ & $\begin{array}{c}-0.044 \\
(0.134)\end{array}$ \\
\hline Before $^{-1}$ & $\begin{array}{c}-\mathbf{0 . 0 4 7} \\
(\mathbf{0 . 0 5 3})\end{array}$ & $\begin{array}{l}-0.059 \\
(0.131)\end{array}$ \\
\hline Before ${ }^{0}$ & $\begin{array}{c}-0.098 * \\
(0.051)\end{array}$ & $\begin{array}{c}-0.206 * \\
(0.112)\end{array}$ \\
\hline After ${ }^{l}$ & $\begin{array}{c}-\mathbf{0 . 2 8 0} * * * \\
(0.073)\end{array}$ & $\begin{array}{c}-0.767 * * * \\
(0.205)\end{array}$ \\
\hline After $^{2+}$ & $\begin{array}{c}-0.247 * * * \\
(0.074)\end{array}$ & $\begin{array}{c}-0.728 * * * * \\
(0.213)\end{array}$ \\
\hline Size & $\begin{array}{c}0.346 * * * \\
(0.029)\end{array}$ & $\begin{array}{c}1.074 * * * \\
(0.088)\end{array}$ \\
\hline Leverage & $\begin{array}{c}-0.002 \\
(0.002)\end{array}$ & $\begin{array}{c}-0.006 \\
(0.004)\end{array}$ \\
\hline$R O A$ & $\begin{array}{c}1.034 * * * \\
(0.149)\end{array}$ & $\begin{array}{c}2.968 * * * \\
(0.379)\end{array}$ \\
\hline Loss & $\begin{array}{c}-0.014 \\
(0.022)\end{array}$ & $\begin{array}{c}-0.051 \\
(0.058)\end{array}$ \\
\hline Cap_inten & $\begin{array}{c}0.428 * * * \\
(0.082)\end{array}$ & $\begin{array}{c}1.338 * * * \\
(0.237)\end{array}$ \\
\hline Int_cov & $\begin{array}{c}0.005 * * * \\
(0.001)\end{array}$ & $\begin{array}{c}0.013 * * * \\
(0.002)\end{array}$ \\
\hline Subord & $\begin{array}{c}-0.117 * * * \\
(0.032)\end{array}$ & $\begin{array}{c}-0.394 * * * \\
(0.088)\end{array}$ \\
\hline LogVol & $\begin{array}{c}-0.536^{* * *} \\
(0.032)\end{array}$ & $\begin{array}{c}-1.548 * * * \\
(0.085)\end{array}$ \\
\hline LogVega & $\begin{array}{c}0.002 \\
(0.008)\end{array}$ & $\begin{array}{c}-0.002 \\
(0.022)\end{array}$ \\
\hline LogDelta & $\begin{array}{c}0.041 * * * \\
(0.011)\end{array}$ & $\begin{array}{c}0.118 * * * \\
(0.029)\end{array}$ \\
\hline Age & $\begin{array}{c}-0.005^{* *} * \\
(0.002)\end{array}$ & $\begin{array}{c}-0.012 * * \\
(0.006)\end{array}$ \\
\hline Tenure & $\begin{array}{c}0.000 \\
(0.003)\end{array}$ & $\begin{array}{c}0.003 \\
(0.008)\end{array}$ \\
\hline Military & $\begin{array}{l}-0.002 \\
(0.044)\end{array}$ & $\begin{array}{c}-0.122 \\
(0.123)\end{array}$ \\
\hline Observations & 13,020 & 13,020 \\
\hline Firm FE & YES & YES \\
\hline Year FE & YES & YES \\
\hline Adjusted R-squared & 0.855 & 0.893 \\
\hline
\end{tabular}




\section{Table 7 Path Analysis}

This table reports the results of path analyses that examine the relation between pilot CEOs and corporate credit ratings through the direct path of rating agencies' assessment of managerial risk tolerance and the indirect paths of the level (Future_TobinQ) and the variance of future firm value (Future_Vol). The following models are estimated:

$$
\begin{aligned}
& \text { Rating } 1 \text { (or Rating2) }=\beta_{0}+\beta_{1} \text { Pilot CEO }+\beta_{2} \text { Future_Tobin } Q+\beta_{3} \text { Future_Vol } \\
& +\beta \mathrm{kControls}+\text { Industry FE }+ \text { Year FE }+\varepsilon \\
& \text { Future_Tobin } Q=\alpha_{0}+\alpha_{1} \text { Pilot CEO }+ \text { Industry FE }+ \text { Year FE }+\mu \\
& \text { Future_Vol }=\delta_{0}+\delta_{1} \text { Pilot CEO+Industry FE }+ \text { Year FE }+\Psi
\end{aligned}
$$

where controls are the control variables included in equation (1); all the variables are defined in Appendix. The path coefficient $\beta_{1}$ is the magnitude of the direct path from Pilot $C E O$ to the rating variables. The path coefficient $\alpha_{1} \times \beta_{2}\left(\delta_{1} \times \beta_{3}\right)$ measures the magnitude of the indirect path from Pilot CEO to the rating variables mediated through Future_TobinQ (Future_Vol). The table reports the path coefficients of interest, $p(X 1, X 2)$, which stands for the standardized path coefficient. The significance of the indirect effect is estimated using the Sobel (1982) test statistics.

\section{Direct Path}

$p($ Pilot CEO, Rating $1 /$ Rating 2$)=\beta_{1}$

\section{Mediated Path for Future_TobinQ}

$p($ Pilot CEO, Future_Tobin $Q)=\alpha_{1}$

$p($ Future_TobinQ, Rating1/Rating2 $)=\beta_{2}$

Total Mediated Path for Futute_TobinQ $\left(=\alpha_{1} \times \beta_{2}\right)$

Mediated Path for Future_Vol

$p($ Pilot CEO, Future_Vol $)=\delta_{1}$

$p($ Future_Vol, Ratingl/Rating 2$)=\beta_{3}$

Total Mediated Path for Future_Vol $\left(=\delta_{1} \times \beta_{3}\right)$

Controls

Industry FE

Year FE

\section{(1)}

Rating1

(2)

Rating2

$-0.249 * * * \quad-0.688 * * *$

$\begin{array}{cc}-0.184^{* * *} & -0.184^{* * *} \\ 0.215^{* * *} & 0.628^{* * *} \\ -0.039^{* * *} & -0.115^{* *}\end{array}$

$0.040^{* *} \quad 0.040^{* *}$

$-0.867 * * * \quad-2.665 * * *$

$-0.035 * * \quad-0.108 * * *$

Yes Yes

Yes Yes

Yes Yes 


\section{Table 8 Cross-sectional Analyses of the Relation between Pilot CEOs and Corporate Credit Ratings}

This table presents the regression results of the cross-sectional analyses of the relation between pilot CEOs and corporate credit ratings conditional on: product market competition (High_HHI), industry growth (HighGrowth), and financial constraints (High_FinCon). High_HHI is an indictor variable that equals one if a firm is in a highly concentrated industry (i.e., the sales concentration of the industry is in the top quantile of the year). HighGrowth is an indicator variable that equals one if a firm is in a high growth industry (i.e., healthcare, medical equipment, computer, and pharmaceutical industry) defined following Bonsall et al. (2016). High_FinCon is an indicator variable that equals one if a firm faces serious financial constraints and delayed investments due to issues with liquidity (i.e., delaycon constructed by Hoberg and Maksimovic (2015) is in the top quantile of the industry-year). The sample period is from 1992 to 2016. All variables are defined in Appendix. Each of the continuous variables is winsorized at the $1 \%$ and $99 \%$ levels to mitigate the effect of outliers. Standard errors are reported in parentheses. $* * *, * *$, and $*$ indicate statistical significance at the $1 \%, 5 \%$, and $10 \%$ levels, respectively, using two-tailed tests and standard errors clustered by firm.

\begin{tabular}{|c|c|c|c|c|c|c|}
\hline Variables & $\begin{array}{c}\text { (1) } \\
\text { Ratingl } \\
\end{array}$ & $\begin{array}{c}\text { (2) } \\
\text { Rating2 }\end{array}$ & $\begin{array}{c}(3) \\
\text { Rating1 }\end{array}$ & $\begin{array}{c}\text { (4) } \\
\text { Rating2 }\end{array}$ & $\begin{array}{c}(5) \\
\text { Rating1 }\end{array}$ & $\begin{array}{c}\text { (6) } \\
\text { Rating2 } \\
\end{array}$ \\
\hline Pilot CEO & $\begin{array}{c}-0.282 * * * \\
(0.059)\end{array}$ & $\begin{array}{c}-0.743 * * * \\
(0.171)\end{array}$ & $\begin{array}{c}-0.195 * * * \\
(0.055)\end{array}$ & $\begin{array}{c}-0.521 * * * \\
(0.161)\end{array}$ & $\begin{array}{c}-0.184 * * * \\
(0.065)\end{array}$ & $\begin{array}{c}-0.524 * * * \\
(0.188)\end{array}$ \\
\hline Pilot CEO $\times$ High_HHI & $\begin{array}{c}0.289 * * * * \\
(0.105)\end{array}$ & $\begin{array}{c}\mathbf{0 . 6 9 5 * * *} \\
(\mathbf{0 . 3 3 6})\end{array}$ & & & & \\
\hline High_HHI & $\begin{array}{c}-0.069 * \\
(0.040)\end{array}$ & $\begin{array}{c}-0.223^{* *} \\
(0.109)\end{array}$ & & & & \\
\hline Pilot CEO $\times$ HighGrowth & & & $\begin{array}{c}-0.546 * * * \\
(0.193)\end{array}$ & $\begin{array}{c}-1.460 * * * \\
(0.546)\end{array}$ & & \\
\hline HighGrowth & & & $\begin{array}{c}0.142 \\
(0.143)\end{array}$ & $\begin{array}{c}0.475 \\
(0.490)\end{array}$ & & \\
\hline Pilot CEO $\times$ High_FinCon & & & & & $\begin{array}{c}-\mathbf{0 . 0 7 6} * * * \\
(0.024)\end{array}$ & $\begin{array}{c}-0.239 * * * \\
(0.070)\end{array}$ \\
\hline High_FinCon & & & & & $\begin{array}{c}-0.281 * * \\
(0.115)\end{array}$ & $\begin{array}{c}-0.554 * \\
(0.313)\end{array}$ \\
\hline Size & $\begin{array}{c}0.310 * * * \\
(0.018)\end{array}$ & $\begin{array}{c}0.941 * * * \\
(0.053)\end{array}$ & $\begin{array}{c}0.310 * * * \\
(0.017)\end{array}$ & $\begin{array}{c}0.940 * * * \\
(0.052)\end{array}$ & $\begin{array}{c}0.289 * * * \\
(0.021)\end{array}$ & $\begin{array}{c}0.884 * * * \\
(0.062)\end{array}$ \\
\hline
\end{tabular}




\begin{tabular}{|c|c|c|c|c|c|c|}
\hline Leverage & $\begin{array}{c}-0.003 \\
(0.002)\end{array}$ & $\begin{array}{c}-0.008 \\
(0.007)\end{array}$ & $\begin{array}{l}-0.003 \\
(0.002)\end{array}$ & $\begin{array}{l}-0.008 \\
(0.007)\end{array}$ & $\begin{array}{c}-0.005 * * * \\
(0.002)\end{array}$ & $\begin{array}{c}-0.015 * * * \\
(0.006)\end{array}$ \\
\hline$R O A$ & $\begin{array}{c}1.116^{* * * *} \\
(0.203)\end{array}$ & $\begin{array}{c}3.488 * * * \\
(0.599)\end{array}$ & $\begin{array}{c}1.110 * * * \\
(0.202)\end{array}$ & $\begin{array}{c}3.466^{* * * *} \\
(0.597)\end{array}$ & $\begin{array}{c}0.957 * * * \\
(0.230)\end{array}$ & $\begin{array}{c}2.600 * * * * \\
(0.645)\end{array}$ \\
\hline Loss & $\begin{array}{c}-0.112 * * * \\
(0.034)\end{array}$ & $\begin{array}{c}-0.344 * * * \\
(0.097)\end{array}$ & $\begin{array}{c}-0.113 * * * \\
(0.034)\end{array}$ & $\begin{array}{c}-0.348 * * * \\
(0.096)\end{array}$ & $\begin{array}{c}-0.095 * * \\
(0.038)\end{array}$ & $\begin{array}{c}-0.313 * * * \\
(0.105)\end{array}$ \\
\hline Cap_inten & $\begin{array}{c}0.069 \\
(0.049)\end{array}$ & $\begin{array}{l}0.272^{*} \\
(0.147)\end{array}$ & $\begin{array}{c}0.072 \\
(0.049)\end{array}$ & $\begin{array}{l}0.279 * \\
(0.147)\end{array}$ & $\begin{array}{c}0.075 \\
(0.056)\end{array}$ & $\begin{array}{c}0.257 \\
(0.168)\end{array}$ \\
\hline Int_cov & $\begin{array}{c}0.008 * * * \\
(0.001)\end{array}$ & $\begin{array}{c}0.023 * * * \\
(0.003)\end{array}$ & $\begin{array}{c}0.008 * * * \\
(0.001)\end{array}$ & $\begin{array}{c}0.023 * * * \\
(0.003)\end{array}$ & $\begin{array}{c}0.008 * * * \\
(0.001)\end{array}$ & $\begin{array}{c}0.023 * * * \\
(0.004)\end{array}$ \\
\hline Subord & $\begin{array}{c}-0.256 * * * \\
(0.037)\end{array}$ & $\begin{array}{c}-0.807 * * * \\
(0.114)\end{array}$ & $\begin{array}{c}-0.255^{* * *} * \\
(0.037)\end{array}$ & $\begin{array}{c}-0.803 * * * \\
(0.113)\end{array}$ & $\begin{array}{c}-0.228 * * * \\
(0.040)\end{array}$ & $\begin{array}{c}-0.715 * * * \\
(0.118)\end{array}$ \\
\hline LogVol & $\begin{array}{c}-0.875^{* * *} * \\
(0.034)\end{array}$ & $\begin{array}{c}-2.716^{* * * *} \\
(0.101)\end{array}$ & $\begin{array}{c}-0.875^{* * * *} \\
(0.034)\end{array}$ & $\begin{array}{c}-2.716^{* * * *} \\
(0.101)\end{array}$ & $\begin{array}{c}-0.875^{* * *} * \\
(0.041)\end{array}$ & $\begin{array}{c}-2.654 * * * \\
(0.119)\end{array}$ \\
\hline LogVega & $\begin{array}{c}0.028 * * * \\
(0.009)\end{array}$ & $\begin{array}{c}0.069 * * * \\
(0.026)\end{array}$ & $\begin{array}{c}0.029 * * * \\
(0.009)\end{array}$ & $\begin{array}{c}0.072 * * * \\
(0.026)\end{array}$ & $\begin{array}{c}0.044 * * * \\
(0.010)\end{array}$ & $\begin{array}{c}0.120 * * * \\
(0.027)\end{array}$ \\
\hline LogDelta & $\begin{array}{c}-0.063 * * * \\
(0.014)\end{array}$ & $\begin{array}{c}-0.183 \text { *** } \\
(0.041)\end{array}$ & $\begin{array}{c}-0.063 * * * * \\
(0.014)\end{array}$ & $\begin{array}{c}-0.184 * * * \\
(0.040)\end{array}$ & $\begin{array}{c}-0.066^{* * * *} \\
(0.015)\end{array}$ & $\begin{array}{c}-0.213 * * * \\
(0.042)\end{array}$ \\
\hline Age & $\begin{array}{c}0.002 \\
(0.002)\end{array}$ & $\begin{array}{c}0.007 \\
(0.006)\end{array}$ & $\begin{array}{c}0.002 \\
(0.002)\end{array}$ & $\begin{array}{c}0.007 \\
(0.006)\end{array}$ & $\begin{array}{c}0.002 \\
(0.003)\end{array}$ & $\begin{array}{c}0.008 \\
(0.007)\end{array}$ \\
\hline Tenure & $\begin{array}{c}0.007 * * \\
(0.003)\end{array}$ & $\begin{array}{l}0.019 * \\
(0.010)\end{array}$ & $\begin{array}{l}0.006^{*} \\
(0.003)\end{array}$ & $\begin{array}{l}0.018^{*} \\
(0.010)\end{array}$ & $\begin{array}{c}0.007^{*} \\
(0.004)\end{array}$ & $\begin{array}{c}0.025^{* *} \\
(0.011)\end{array}$ \\
\hline Military & $\begin{array}{l}-0.027 \\
(0.041)\end{array}$ & $\begin{array}{l}-0.108 \\
(0.122)\end{array}$ & $\begin{array}{l}-0.020 \\
(0.041)\end{array}$ & $\begin{array}{l}-0.091 \\
(0.121)\end{array}$ & $\begin{array}{c}0.018 \\
(0.046)\end{array}$ & $\begin{array}{l}-0.019 \\
(0.133)\end{array}$ \\
\hline Future_Vol & $\begin{array}{c}-0.349 * * * \\
(0.029)\end{array}$ & $\begin{array}{c}-1.034 * * * \\
(0.084)\end{array}$ & $\begin{array}{c}-0.349 * * * \\
(0.029)\end{array}$ & $\begin{array}{c}-1.032 * * * \\
(0.084)\end{array}$ & $\begin{array}{c}-0.369 * * * \\
(0.033)\end{array}$ & $\begin{array}{c}-1.112 * * * \\
(0.091)\end{array}$ \\
\hline Future_TobinQ & $\begin{array}{c}0.185^{* * *} * \\
(0.018)\end{array}$ & $\begin{array}{c}0.547 * * * \\
(0.053)\end{array}$ & $\begin{array}{c}0.182^{* * *} * \\
(0.018)\end{array}$ & $\begin{array}{c}0.538 * * * \\
(0.052)\end{array}$ & $\begin{array}{c}0.158 * * * \\
(0.020)\end{array}$ & $\begin{array}{c}0.489 * * * \\
(0.060)\end{array}$ \\
\hline Industry FE & YES & YES & YES & YES & YES & YES \\
\hline Year FE & YES & YES & YES & YES & YES & YES \\
\hline Adjusted R-squared & 0.665 & 0.699 & 0.666 & 0.699 & 0.666 & 0.702 \\
\hline Observations & 11,619 & 11,619 & 11,619 & 11,619 & 7,063 & 7,063 \\
\hline
\end{tabular}

